\title{
Experiments on liquid immiscibility along tholeiitic liquid lines of descent
}

\author{
Bernard Charlier · Timothy L. Grove
}

Received: 31 October 2011/Accepted: 25 January 2012/Published online: 9 February 2012

(C) Springer-Verlag 2012

\begin{abstract}
Crystallization experiments have been conducted on compositions along tholeiitic liquid lines of descent to define the compositional space for the development of silicate liquid immiscibility. Starting materials have 46-56 wt $\% \mathrm{SiO}_{2}, 11.7-17.7 \mathrm{wt} \% \mathrm{FeO}_{\text {tot }}$, and $\mathrm{Mg}$ number between 0.29 and 0.36 . These melts fall on the basaltic trends relevant for Mull, Iceland, Snake River Plain lavas and for the Sept Iles layered intrusion, where large-scale liquid immiscibility has been recognized. At one atmosphere under anhydrous conditions, immiscibility develops below $1,000-1,020^{\circ} \mathrm{C}$ in all of these compositionally diverse lavas. Extreme iron enrichment is not necessary; immiscibility also develops during iron depletion and silica enrichment. Variations in melt composition control the development of silicate liquid immiscibility along the tholeiitic trend. Elevation of $\mathrm{Na}_{2} \mathrm{O}+\mathrm{K}_{2} \mathrm{O}+$ $\mathrm{P}_{2} \mathrm{O}_{5}+\mathrm{TiO}_{2}$ promotes the development of two immiscible liquids. Increasing melt $\mathrm{CaO}$ and $\mathrm{Al}_{2} \mathrm{O}_{3}$ stabilizes a singleliquid field. New data and published phase equilibria show that anhydrous, low-pressure fractional crystallization is the most favorable condition for unmixing during differentiation. Pressure inhibits immiscibility because it expands the stability field of high-Ca clinopyroxene, which reduces the proportion of plagioclase in the crystallizing assemblage, thus enhancing early iron depletion. Magma mixing between primitive basalt and Fe-Ti-P-rich ferrobasalts can serve to elevate phosphorous and alkali
\end{abstract}

Communicated by J. Hoefs.

B. Charlier $(\square)$. T. L. Grove

Department of Earth, Atmospheric and Planetary Sciences,

Massachusetts Institute of Technology, Cambridge,

MA 02139, USA

e-mail: charlier@mit.edu contents and thereby promote unmixing. Water might decrease the temperature and size of the two-liquid field, potentially shifting the binodal (solvus) below the liquidus, leading the system to evolve as a single-melt phase.

Keywords Experimental petrology - Layered intrusions . Binodal $\cdot$ Solvus $\cdot$ Basalt $\cdot$ Ferrobasalt

\section{Introduction}

The onset of silicate liquid immiscibility along the tholeiitic liquid line of descent is debated (Veksler et al. 2007, 2008; McBirney 2008; Morse 2008; Philpotts 2008; Veksler 2009), and the required degree of enrichment in iron, or any other elements that expand the immiscibility field, is poorly constrained. Indeed, most experiments on dry tholeiitic basalts have been performed at temperatures higher than $1,040-1,050^{\circ} \mathrm{C}$ (Grove and Bryan 1983; Juster et al. 1989; Toplis and Carroll 1995; Villiger et al. 2004; Thy et al. 2006). This is above the binodal surface (or solvus), estimated to be around $1,000-1,020^{\circ} \mathrm{C}$ (Philpotts 1979; Philpotts and Doyle 1983), which must be passed in order to reach the two-liquid field. Moreover, under equilibrium crystallization, the most primitive compositions do not evolve beyond the peritectic reaction olivine + liquid $=$ pigeonite + plagioclase + augite (Grove et al. 1992), which is at a higher temperature compared to the binodal. Experiments on liquid immiscibility have mainly been performed on simplified systems (e.g., Roedder 1978; Bogaerts and Schmidt 2006). Consequently, even though phase relations in the system $\mathrm{K}_{2} \mathrm{O}-\mathrm{FeO}-\mathrm{Al}_{2} \mathrm{O}_{3}-\mathrm{SiO}_{2}$ are well known (Roedder 1978; Visser and Koster van Groos 1979a; Freestone and Powell 1983) and the effects of other elements such as $\mathrm{P}_{2} \mathrm{O}_{5}, \mathrm{TiO}_{2}, \mathrm{CaO}$, and $\mathrm{MgO}$ in reducing or 
expanding the immiscibility field have been experimentally identified (Watson 1976; Visser and Koster van Groos 1979b; Naslund 1983; Bogaerts and Schmidt 2006), direct application of these results to complex natural basaltic systems is not straightforward. In this study, we define the compositional space for the development of immiscibility during tholeiitic basalt differentiation. We then discuss the roles of phosphorous and alkalis in the melt, crystallization temperature and pressure, equilibrium versus fractional crystallization, oxygen fugacity, magma mixing, and water content in favoring or inhibiting the development of silicate liquid immiscibility.

We have performed anhydrous one atmosphere crystallization experiments between 1,040 and $940^{\circ} \mathrm{C}$ on evolved basaltic compositions. Selected starting materials, supposed to be close to the onset of immiscibility, are representative of compositions that define classical tholeiitic trends such as those at Iceland (composition I; Carmichael 1964), Mull (composition M; Kerr et al. 1999), Snake River Plain (composition S; Leeman et al. 1976), and the Sept Iles intrusive suite (composition SI; Namur et al. 2011). In the Sept Iles layered intrusion, large-scale liquid immiscibility has been recorded in cumulates (Charlier et al. 2011), and immiscible liquid pairs are commonly observed in the mesostasis of basalts from tholeiitic provinces (Philpotts 1982). Our experiments show that silicate liquid immiscibility develops over a large compositional range at temperatures and degrees of fractional crystallization that have so far been poorly explored in low-pressure anhydrous experiments.

We use the terms binodal, binodal curve, and binodal surface to define the field of liquid immiscibility in silicate melts. The use of 'solvus', although popular in the geological literature, should be restricted to solid solutions.

\section{Experimental and analytical procedures}

\section{Starting materials}

Experiments have been performed on representative compositions along typical tholeiitic liquid lines of descent, either after silica enrichment and iron depletion due to $\mathrm{Fe}-\mathrm{Ti}$ oxide fractionation (compositions SI-Sept Iles and M-Mull) or close to maximum iron enrichment (compositions I-Iceland and S-Snake River Plain). SI is a fine-grained monzonite from a dyke cross-cutting the Sept Iles layered intrusion, which plots just before the gap in intermediate compositions observed in the trend of liquid evolution (Namur et al. 2011). Composition M, based on data from the Mull Tertiary volcano by Kerr et al. (1999), is an intermediate basalt crystallized after $\mathrm{Fe}-\mathrm{Ti}$ oxide saturation and at the maximum $\mathrm{P}_{2} \mathrm{O}_{5}$ content, before the onset of apatite crystallization. Composition I is similar to tholeiitic lavas from the Thingmuli volcano (Carmichael 1964), and composition S corresponds to high-Fe Holocene lavas from Craters of the Moon National Monument (Leeman et al. 1976). The $\mathrm{Na}_{2} \mathrm{O}$ content of these last two compositions is slightly lower than that of natural compositions. Selected starting materials display a large compositional range with 46-55 wt $\% \mathrm{SiO}_{2}, 11.7-17.3$ wt $\% \mathrm{FeO}_{\text {tot }}, 2.5-6.4 \mathrm{wt} \% \mathrm{Na}_{2} \mathrm{O}+\mathrm{K}_{2} \mathrm{O}$, and an $\mathrm{Mg}$ number of $0.29-0.36$ (Table 1).

Starting compositions were prepared by mixing high purity oxides and silicates. We used $\mathrm{SiO}_{2}, \mathrm{TiO}_{2}, \mathrm{Al}_{2} \mathrm{O}_{3}$, $\mathrm{MnO}, \mathrm{MgO}, \mathrm{CaSiO}_{3}, \mathrm{Na}_{2} \mathrm{SiO}_{3}$, and $\mathrm{K}_{2} \mathrm{Si}_{4} \mathrm{O}_{9}$ in the appropriate proportions. Iron was added as $\mathrm{Fe}_{2} \mathrm{O}_{3}$ and $\mathrm{Fe}$ metal sponge in stoichiometric proportions to produce $\mathrm{FeO}$. Phosphorous was added as apatite. The reagents were mixed under ethanol in an agate mortar for $5 \mathrm{~h}$. The $\mathrm{Fe}$ sponge was then added to the mixture and ground for an additional $1 \mathrm{~h}$. The mixtures were then conditioned for $48 \mathrm{~h}$ at one atmosphere at $900^{\circ} \mathrm{C}$ in a DelTech vertical gasmixing furnace at an oxygen fugacity corresponding to the QFM buffer. SI is a crushed natural sample (03-41; Namur et al. 2011).

\section{Experimental techniques}

Experiments at one atmosphere were performed at MIT in vertical-tube DelTech quenching furnaces, with a $\mathrm{CO}_{2}-\mathrm{H}_{2}$ gas atmosphere. The oxygen fugacity was monitored using a $\mathrm{ZrO}_{2}-\mathrm{CaO}$ oxygen cell and was kept near the QFM buffer. The sample material for these experiments

Table 1 Compositions of starting materials (wt $\%$ )

\begin{tabular}{lllll}
\hline & $\mathrm{SI}$ & $\mathrm{M}$ & $\mathrm{I}$ & $\mathrm{S}$ \\
$n^{\mathrm{a}}$ & 16 & 17 & 20 & 21 \\
\hline $\mathrm{SiO}_{2}$ & $55.2(6)^{\mathrm{b}}$ & $54.9(8)$ & $50.0(5)$ & $45.7(5)$ \\
$\mathrm{TiO}_{2}$ & $2.39(12)$ & $2.40(8)$ & $3.54(7)$ & $3.42(16)$ \\
$\mathrm{Al}_{2} \mathrm{O}_{3}$ & $13.8(1)$ & $13.4(1)$ & $13.1(1)$ & $13.8(1)$ \\
$\mathrm{FeO}$ & $11.7(5)$ & $14.4(6)$ & $14.8(3)$ & $17.3(2)$ \\
$\mathrm{MnO}$ & $0.18(2)$ & $0.19(2)$ & $0.20(2)$ & $0.31(1)$ \\
$\mathrm{MgO}$ & $2.81(13)$ & $3.35(7)$ & $4.70(15)$ & $4.24(14)$ \\
$\mathrm{CaO}$ & $5.39(21)$ & $6.36(9)$ & $8.90(14)$ & $7.77(10)$ \\
$\mathrm{Na} 2 \mathrm{O}$ & $4.05(17)$ & $2.31(9)$ & $2.05(7)$ & $2.35(9)$ \\
$\mathrm{K}_{2} \mathrm{O}$ & $2.31(11)$ & $1.45(8)$ & $0.40(5)$ & $1.53(9)$ \\
$\mathrm{P}_{2} \mathrm{O}_{5}$ & $0.78(4)$ & $0.92(3)$ & $1.19(12)$ & $2.24(14)$ \\
$\mathrm{Total}$ & 98.61 & 99.68 & 98.88 & 98.66 \\
$\mathrm{Mg \#}$ & 0.30 & 0.29 & 0.36 & 0.30 \\
\hline
\end{tabular}

${ }^{a}$ Number of microprobe analyses

b One standard deviation of replicate analyses in terms of least unit cited 
consisted of ca. $50 \mathrm{mg}$ of the oxide mixture mixed with polyvinyl alcohol as a binder. The pellet was prepared on an iron-platinum alloy loop, which had been previously annealed with 7-9 wt $\% \mathrm{Fe}$ added by electroplating to prevent $\mathrm{Fe}$ loss to the alloy during the experiment (Grove 1981). The sample temperature was measured using a Pt$\mathrm{Pt}_{90} \mathrm{Rh}_{10}$ thermocouple calibrated to the melting points of $\mathrm{NaCl}, \mathrm{Au}$, and $\mathrm{Pd}$. The thermocouple was placed in the hotspot of the furnace, where the thermal gradient is $<1^{\circ} \mathrm{C}$. The sample was suspended alongside the thermocouple such that they were at the same level within the furnace. The temperature reproducibility of this arrangement is better than $5^{\circ} \mathrm{C}$.

Both isothermal and constant cooling rate experiments were performed. For the isothermal experiments, the sample was held above the liquidus temperature for ca. $24 \mathrm{~h}$ before dropping to the target temperature and equilibrating for 6 days. Samples for cooling rate experiments were loaded into the furnace above the liquidus temperature and then cooled at $1{ }^{\circ} \mathrm{C} / \mathrm{h}$ until they reached the final temperature. These runs were then equilibrated at the final temperature for 3-4 additional days. All samples were drop-quenched into water.
Electron microprobe analyses

Compositions of the minerals and glasses were analyzed using wavelength dispersive spectrometry on the 5-spectrometer JEOL 8200 electron microprobe at MIT. Natural and synthetic primary and secondary standards were used, and the CITZAF online data correction package was used for all analyses (Armstrong 1995). Mineral analyses were performed with a $15 \mathrm{kV}$ accelerating voltage and a beam current of $10 \mathrm{nA}$, utilizing a focused beam spot. Glass compositions were measured using a $10 \mu \mathrm{m}$ defocused beam, $10 \mathrm{nA}$ beam current, and $15 \mathrm{kV}$ accelerating voltage.

Experimental results

\section{Phase equilibria and immiscible textures}

The phase relations and run conditions for compositions SI, $\mathrm{M}$, I, and $\mathrm{S}$ are reported in Table 2. Plagioclase and ilmenite are stable liquidus phases in all experiments. Other crystalline phases observed are olivine, augite, pigeonite, magnetite, whitlockite, and a silica phase. Olivine is a liquidus phase at $1,040^{\circ} \mathrm{C}$ for all four starting
Table 2 Experimental conditions and products

gl glass, $p l$ plagioclase, ol olivine, aug augite, pig pigeonite, il ilmenite, $m t$ magnetite, qt quartz, wht whitlockite, ol olivine with pyroxene reaction rim, pig pigeonite core surrounded by augite

* Diffuse immiscibility

\begin{tabular}{|c|c|c|c|c|c|}
\hline Run & $\begin{array}{l}\text { Starting } \\
\mathrm{T}\left({ }^{\circ} \mathrm{C}\right)\end{array}$ & $\begin{array}{l}\text { Final } \\
\mathrm{T}\left({ }^{\circ} \mathrm{C}\right)\end{array}$ & Time (h) & $\begin{array}{l}\text { Cooling } \\
\text { method }\end{array}$ & Phases \\
\hline SI-4 & 1,100 & 1,100 & 24 & Isothermal & $\mathrm{gl}$ \\
\hline SI-3 & 1,100 & 1,041 & 166 & Isothermal & $1 \mathrm{gl}, \mathrm{pl}, \mathrm{ol}, \mathrm{il}$ \\
\hline SI-13 & 1,100 & 1,020 & 144 & $1^{\circ} \mathrm{C} / \mathrm{h}$ & $2 \mathrm{gl}, \mathrm{pl}$, ol, aug, pig, il, mt \\
\hline SI-7 & 1,100 & 1,006 & 162 & Isothermal & $2 \mathrm{gl}, \mathrm{pl}$, ol, aug, il, mt, wht \\
\hline SI-5 & 1,100 & 1,006 & 190 & $1^{\circ} \mathrm{C} / \mathrm{h}$ & $2 \mathrm{gl}, \mathrm{pl}$, aug, pig, il, mt, wht \\
\hline SI-8 & 1,100 & 963 & 185 & $1^{\circ} \mathrm{C} / \mathrm{h}$ & $2 \mathrm{gl}, \mathrm{pl}$, ol, aug, il, mt, wht \\
\hline SI-9 & 1,100 & 938 & 234 & $1^{\circ} \mathrm{C} / \mathrm{h}$ & $2 \mathrm{gl}, \mathrm{pl}, \mathrm{ol}$, aug, il, mt, wht \\
\hline M-1 & 1,100 & 1,100 & 24 & Isothermal & $\mathrm{gl}$ \\
\hline M-2 & 1,100 & 1,041 & 166 & Isothermal & $1 \mathrm{gl}, \mathrm{pl}, \mathrm{ol}, \mathrm{pig}, \mathrm{il}$ \\
\hline M-9 & 1,100 & 1,020 & 144 & $1^{\circ} \mathrm{C} / \mathrm{h}$ & $2 \mathrm{gl}, \mathrm{pl}, \mathrm{ol}, \mathrm{pig}, \mathrm{il}, \mathrm{mt}$ \\
\hline M-4 & 1,100 & 1,006 & 162 & Isothermal & $2 \mathrm{gl}, \mathrm{pl}$, pig, il, mt, wht \\
\hline M-5 & 1,100 & 1,005 & 187 & $1^{\circ} \mathrm{C} / \mathrm{h}$ & $2 \mathrm{gl}, \mathrm{pl}, \mathrm{ol}, \mathrm{pig}, \mathrm{il}, \mathrm{mt}$, wht \\
\hline M-6 & 1,100 & 963 & 185 & $1^{\circ} \mathrm{C} / \mathrm{h}$ & $2 \mathrm{gl}, \mathrm{pl}$, pig, il, mt, wht \\
\hline M-7 & 1,100 & 938 & 234 & $1^{\circ} \mathrm{C} / \mathrm{h}$ & 2 gl, pl, pig, il, mt, wht \\
\hline $\mathrm{I}-4$ & 1,140 & 1,140 & 24 & Isothermal & $\mathrm{gl}$ \\
\hline $\mathrm{I}-1$ & 1,120 & 1,041 & 162 & Isothermal & $1 \mathrm{gl}, \mathrm{pl}, \mathrm{ol}, \mathrm{pig}, \mathrm{il}$ \\
\hline I-6 & 1,120 & 1,023 & 144 & $1^{\circ} \mathrm{C} / \mathrm{h}$ & $1 \mathrm{gl}$, pl, aug, (pig), il, wht, qt \\
\hline $\mathrm{I}-3$ & 1,130 & 1,005 & 234 & $1^{\circ} \mathrm{C} / \mathrm{h}$ & $2 \mathrm{gl}$, pl, aug, (pig), il, wht, qt \\
\hline $\mathrm{I}-5$ & 1,120 & 964 & 280 & $1^{\circ} \mathrm{C} / \mathrm{h}$ & $2 \mathrm{gl}, \mathrm{pl}$, aug, (pig), il, mt, wht, qt \\
\hline $\mathrm{S}-2$ & 1,120 & 1,120 & 24 & Isothermal & gl \\
\hline S-1 & 1,120 & 1,041 & 162 & Isothermal & $1 \mathrm{gl}, \mathrm{pl}$, ol, il, mt, wht \\
\hline S-6 & 1,130 & 1,023 & 144 & $1^{\circ} \mathrm{C} / \mathrm{h}$ & $2 \mathrm{gl}^{*}, \mathrm{pl}, \mathrm{ol}, \mathrm{il}, \mathrm{wht}$ \\
\hline S-3 & 1,130 & 1,005 & 234 & $1^{\circ} \mathrm{C} / \mathrm{h}$ & $2 \mathrm{gl} 1^{*}, \mathrm{pl}, \mathrm{ol}$, aug, il, wht \\
\hline S-5 & 1,100 & 1,006 & 181 & $1^{\circ} \mathrm{C} / \mathrm{h}$ & $2 \mathrm{gl}^{*}, \mathrm{pl},(\mathrm{ol})$, aug, il, mt, wht \\
\hline
\end{tabular}


compositions but disappears at lower temperature or is surrounded by an augite reaction rim (composition $\mathrm{S}$ ). It reappears at $960^{\circ} \mathrm{C}$ for composition SI. Whitlockite saturates between 1,040 and $1,020^{\circ} \mathrm{C}$. Although isothermal experiments should be preferable to cooling rate experiments for the reconstruction of liquid lines of descent, crystals and immiscible liquids produced isothermally were rarely of sufficient size to be confidently analyzed with the microprobe. Immiscibility starts developing between 1,023 and $1,005^{\circ} \mathrm{C}$, this temperature being the same in isothermal and cooling rate experiments. The main consequences of cooling rate experiments are the preservation of pigeonite cores surrounded by augite in experiments I-6, I-3, and I-5, and the presence of olivine (surrounded by Fe-rich augite) with higher Fo content in experiment S-5 compared to runs at higher temperatures on the same $\mathrm{S}$ starting material (S-1, S-6 and S-3). Pyroxenes and plagioclase are also compositionally zoned; we therefore measured the rims in contact with glass. Experimental liquids obtained in this study are the products of crystallization conditions intermediate between equilibrium and fractional. This is due to incomplete peritectic reactions (augite overgrowth on olivine) and mineral zonings (particularly for plagioclase and pyroxenes). Some early crystallized minerals have thus been partly subtracted from the system, preventing complete reequilibration with decreasing temperature.

Sharp two-liquid interfaces are usually observed (Fig. 1a-c). Fe-rich globules develop in the Si-rich melt for composition SI (Fig. 1a), while Si-rich melts are embedded in an Fe-rich melt for composition I (Fig. 1c). The two liquids occur in similar proportions in composition $\mathrm{M}$ and develop two generations of droplets (Fig. 1b). The formation of two generations results from early development of the same proportion of large droplets of two immiscible melts at higher temperature (a single generation is observed $15^{\circ} \mathrm{C}$ above in experiment M-9) and further reequilibration with decreasing temperature by unmixing of one melt in the other. No compositional difference between small and large droplets has been observed, supporting complete reequilibration of the two liquids. For composition S, experiments produce a wide range of liquid compositions, with diffuse contacts between the two liquids (experiments S-6, S-3, and
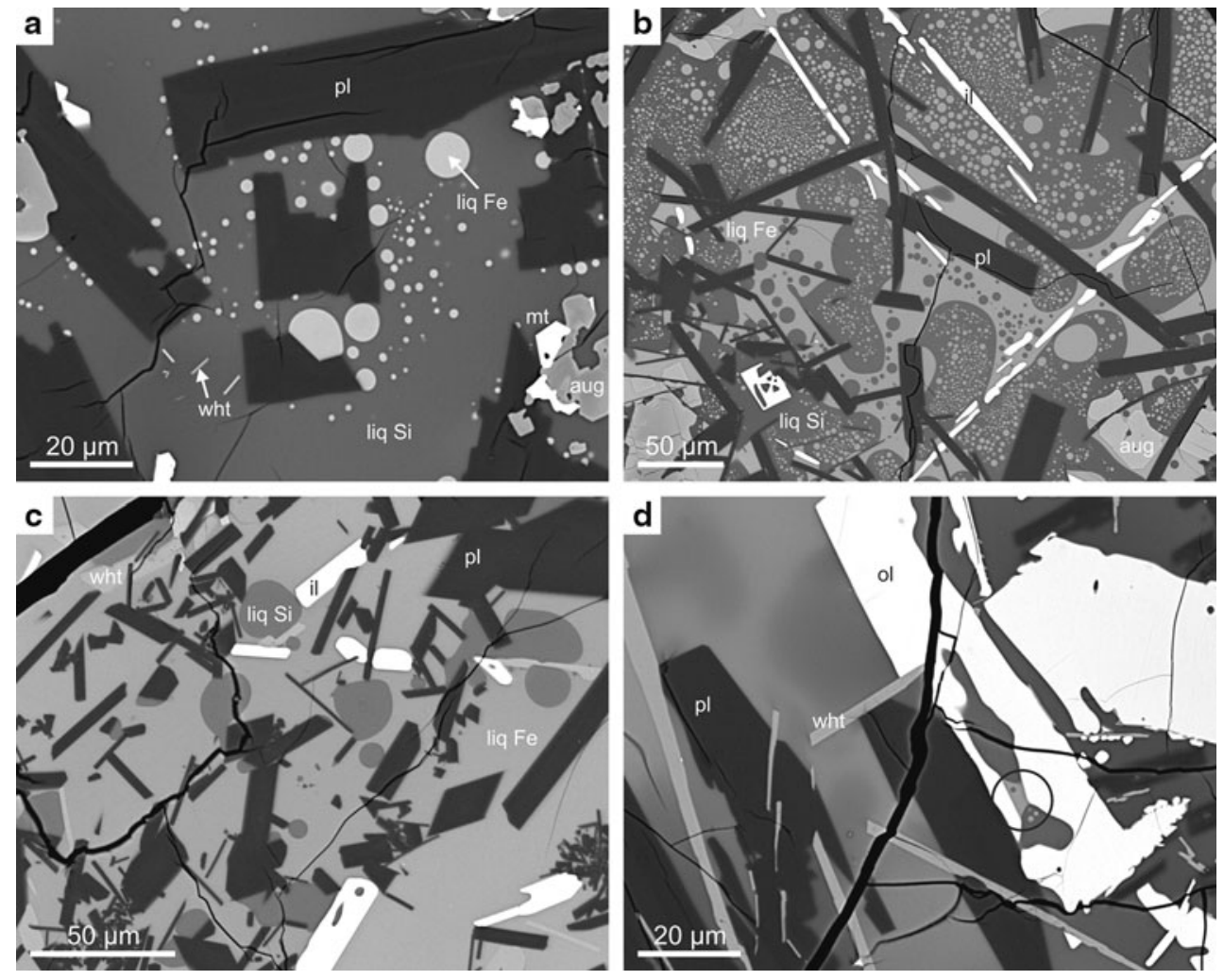

Fig. 1 Back-scattered electron images of experimental products. a Experiment SI-5 $\left(1,006^{\circ} \mathrm{C}\right)$ showing Fe-rich immiscible globules in Si-rich liquid. Fe-rich globules nucleate locally at the contact with plagioclase; b Experiment M-5 $\left(1,005^{\circ} \mathrm{C}\right)$ showing two generations of immiscible globules; c Experiment I-3 $\left(1,005^{\circ} \mathrm{C}\right)$ with $\mathrm{Si}$-rich immiscible globules embedded in Fe-rich liquid; d Experiment S-3

$\left(1,005^{\circ} \mathrm{C}\right)$ with diffuse contacts between the two liquids (see upper left). Two-liquid interfaces locally develop (see the circle). liq Si silica-rich immiscible liquid, liq $F e$ iron-rich immiscible liquid, $p l$ plagioclase, aug augite, ol olivine, $m t$ magnetite, il ilmenite, wht whitlockite 
S-5). Two-liquid interfaces are locally observed in these experiments (Fig. 1d). The composition of the immiscible pairs has been identified by measuring a large number of points and averaging the 4-5 most extreme compositions. Similar textures between immiscible melts have been described by Longhi (1990) and Veksler et al. (2006). This feature is interpreted to result from a low efficiency of meltmelt separation for this composition, possibly caused by a close proximity to the closure of miscibility gap in multicomponent composition space, just below the binodal.

\section{Liquid compositions}

The composition of liquids before reaching immiscibility ranges from 48.6 to $60.4 \mathrm{wt} \% \mathrm{SiO}_{2}, 9.8-21.0 \mathrm{wt} \% \mathrm{FeO}$, and an Mg-number of 0.15-0.24 (Table 3). These liquids are saturated with plagioclase, olivine, ilmenite, \pm pigeonite, \pm augite, \pm magnetite, \pm whitlockite, \pm quartz. Using the parameter NBO/T (NBO: number of non-bridging oxygens, $\mathrm{T}$ : tetrahedrally coordinated network former cations; Mysen 1983), which expresses the degree of polymerization in silicate melts, the data illustrate an expansion of the two-melt field with decreasing temperature (Fig. 2). Note the narrower two-liquid field is observed for compositions $\mathrm{S}$, in which diffuse immiscibility has been observed. Experimental melts are also plotted in binary compositional diagrams (Fig. 3). Fe-rich immiscible melts have 51.7-31.2 $\mathrm{wt} \% \mathrm{SiO}_{2}$ and $18.2-32.4 \mathrm{wt} \% \mathrm{FeO}_{\text {tot }}$; Si-rich melts have 60.4-76.2 wt $\% \mathrm{SiO}_{2}$ and 3.7-12.5 wt\% $\mathrm{FeO}_{\text {tot }}$. The $\mathrm{Mg}$-number of the Fe-rich melt is slightly higher than the equilibrium Si-rich melt. $\mathrm{Al}_{2} \mathrm{O}_{3}, \mathrm{Na}_{2} \mathrm{O}$, and $\mathrm{K}_{2} \mathrm{O}$ are enriched in the Si-rich melts, while $\mathrm{TiO}_{2}, \mathrm{FeO}_{\text {tot }}, \mathrm{MgO}, \mathrm{CaO}$, and $\mathrm{P}_{2} \mathrm{O}_{5}$ are enriched in the Fe-rich melt. The tie lines between immiscible pairs, which define a locus for the development of immiscibility, apparently cross the liquid lines of descent obtained by Juster et al. (1989) for the Galapagos spreading center and by Toplis and Carroll (1995) for the parental magma of the Skaergaard layered intrusion proposed by Brooks and Nielsen (1978). However, these two liquid lines of descent, also determined by one atmosphere experiments at QFM conditions but with no phosphorous, both lie above the binodal (Fig. 4).

Two contrasting evolution trends are displayed by starting compositions SI and I. SI contains $55.2 \mathrm{wt} \% \mathrm{SiO}_{2}$

Fig. 2 Temperature as a function of the degree of polymerization $(\mathrm{NBO} / \mathrm{T})$ of experimental melts and shape of the binodal curves. NBO/T calculated assuming $\mathrm{T}=\mathrm{Si}+\mathrm{Al}+\mathrm{P}+\mathrm{Ti}$. Gray stars are homogeneous melts, black circles are Fe-rich immiscible melts, and white circles are Si-rich immiscible melts

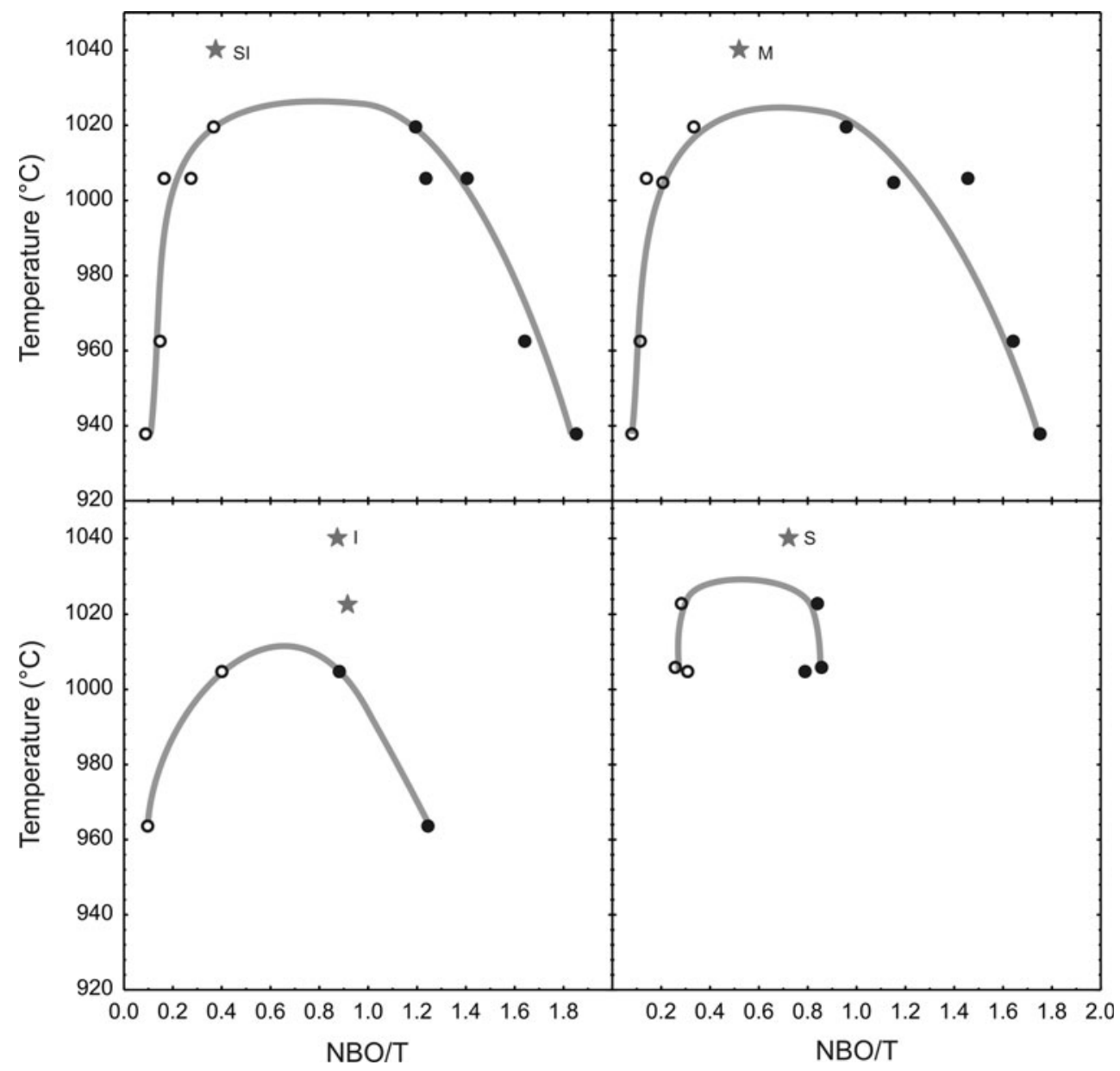


Fig. 3 Experimental glasses plotted for selected major element oxides. Gray curves labeled $T \& C$ and $J \& G$ are the liquid lines of descent of Toplis and Carroll (1995) and Juster et al. (1989), respectively. a-d $\mathrm{FeO}_{\text {tot }}$ versus $\mathrm{SiO}_{2}$ for each starting materials SI, M, I, and S and their crystallization experiments; $\mathrm{e} \mathrm{CaO}$ versus $\mathrm{Al}_{2} \mathrm{O}_{3}$ with all starting materials and experimental glasses; f $\mathrm{TiO}_{2}$ versus $\mathrm{MgO}$. White stars are starting compositions, gray stars are homogeneous melts, black circles are Fe-rich immiscible melts, and white circles are Si-rich immiscible melts. Tie lines join immiscible pairs
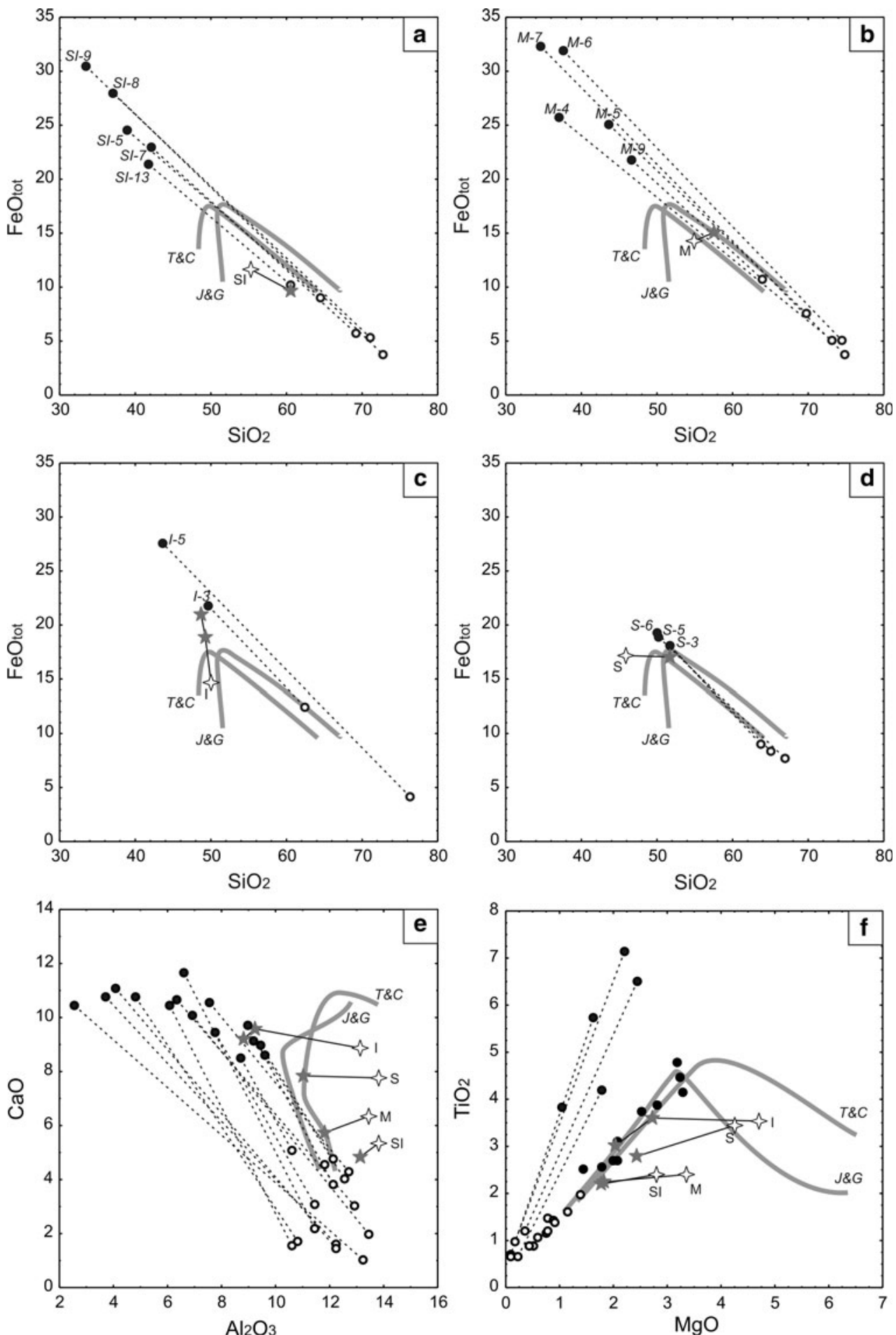

and evolves to $60.4 \% \mathrm{SiO}_{2}$ before reaching immiscibility, while $\mathrm{FeO}_{\text {tot }}$ decreases from 11.7 to $9.78 \mathrm{wt} \%$. This melt is clearly on the silica enrichment and iron depletion trend. The starting composition I has $50.0 \mathrm{wt} \% \mathrm{SiO}_{2}$, which decreases to 49.1 and 48.6 before the onset of immiscibility, with corresponding $\mathrm{FeO}_{\text {tot }}$ enrichment from
14.4, to 18.9 and $21.0 \mathrm{wt} \%$. The low alkali content of starting composition I explains the high-Fe enrichment (Veksler 2009). Both liquid lines of descent reach the twoliquid stability field, but silica-rich melt is dominant for SI compositions, while iron-rich melt is much more abundant for I compositions (Fig. 1a-c). 


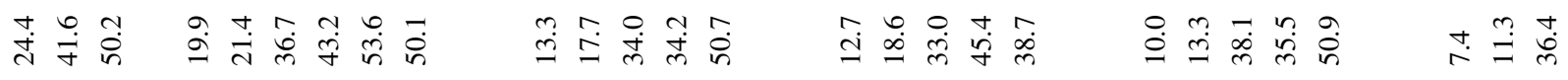

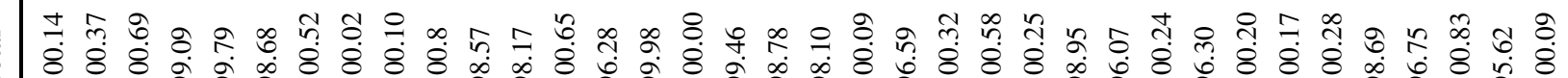

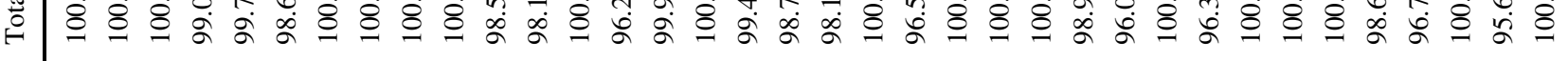

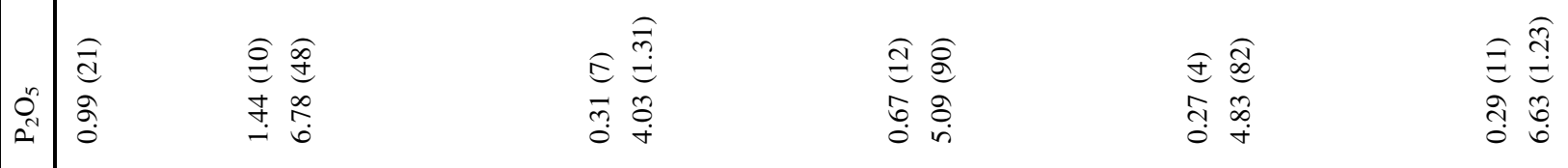

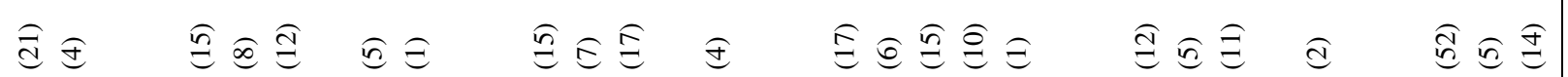
至

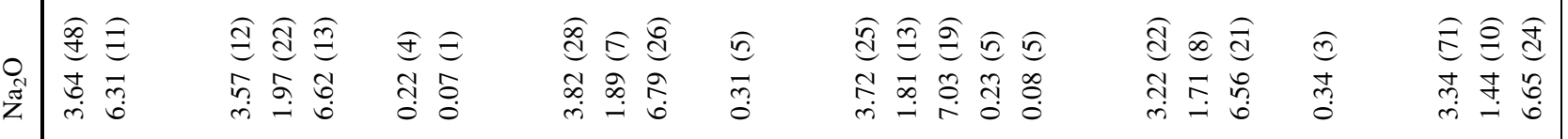

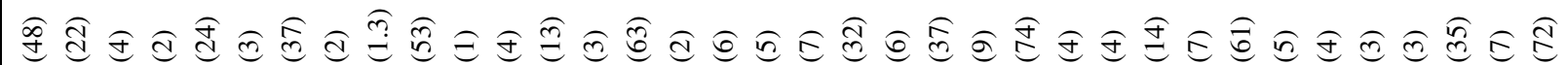

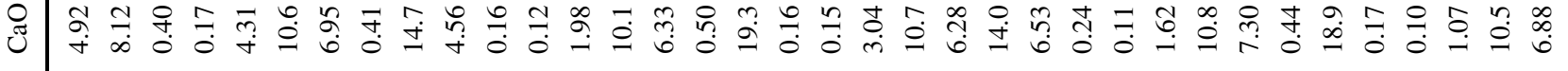

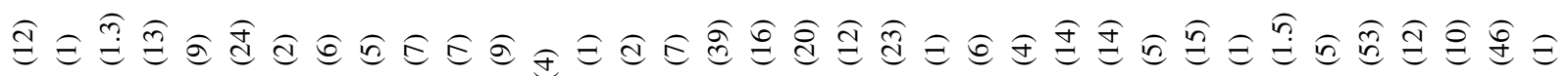

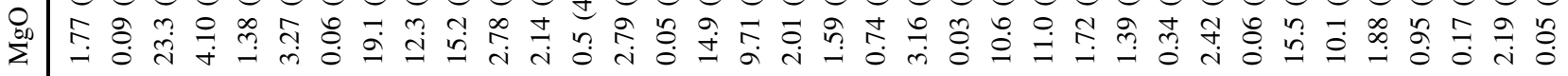

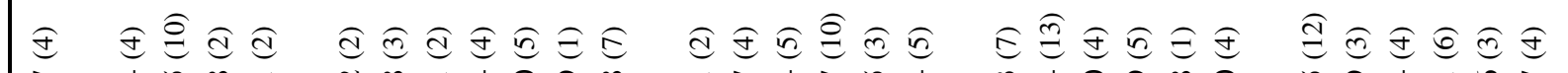

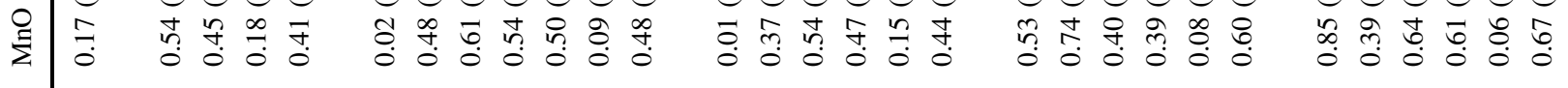

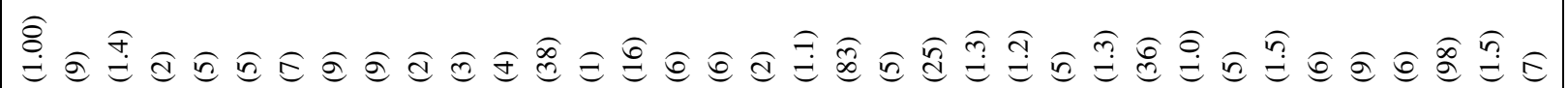

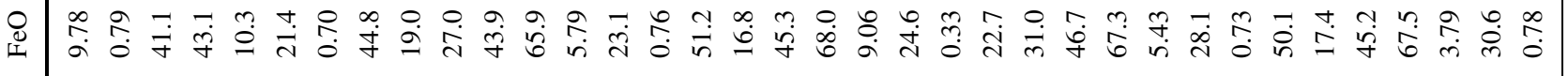

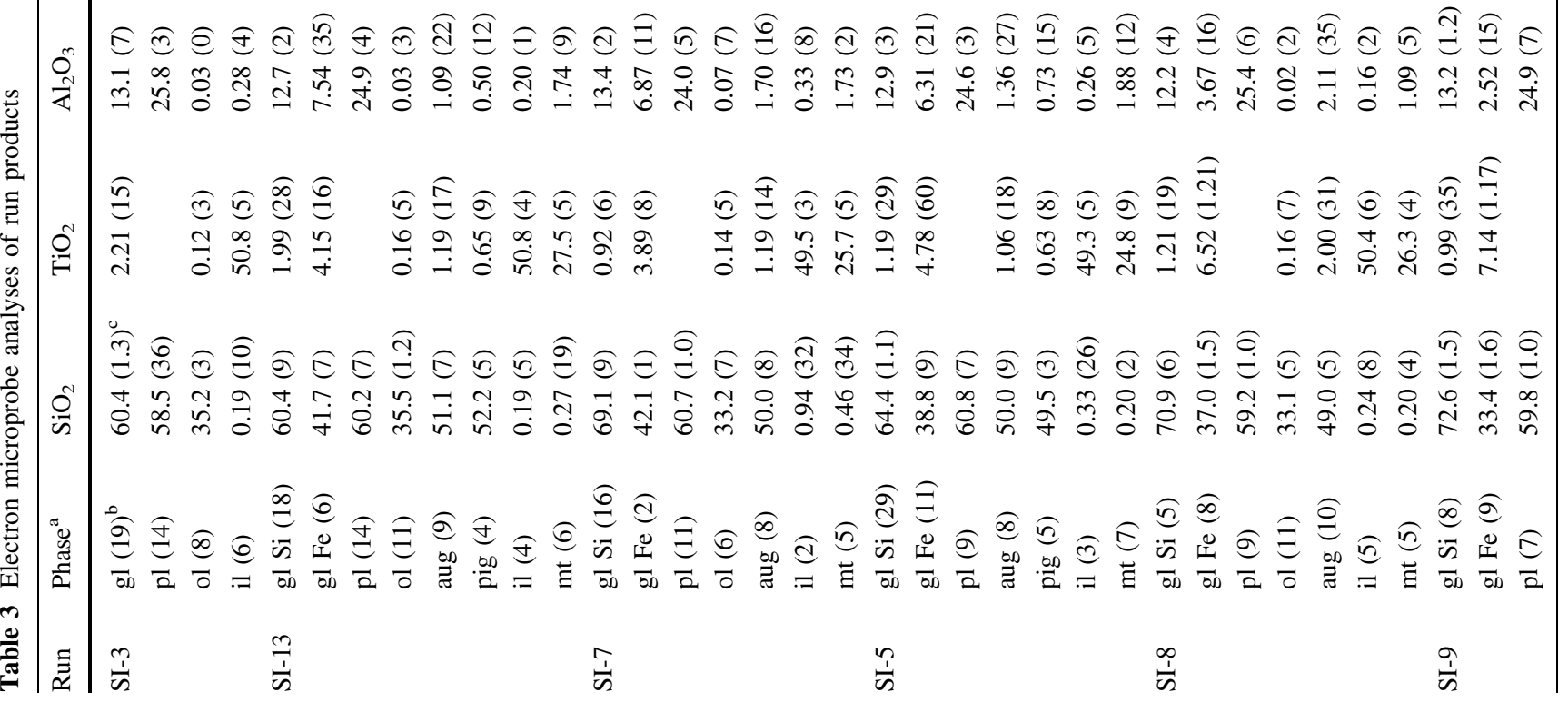




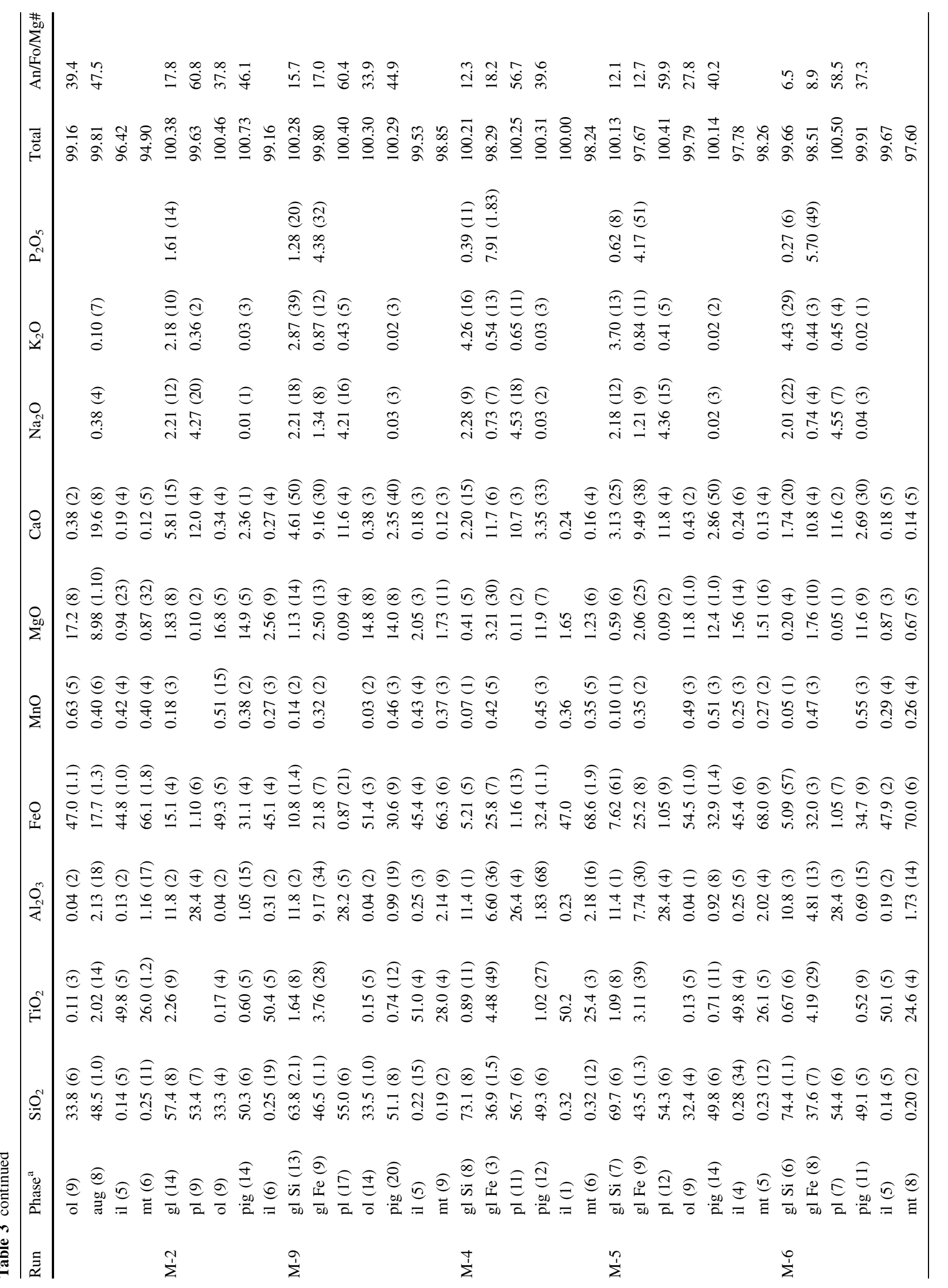




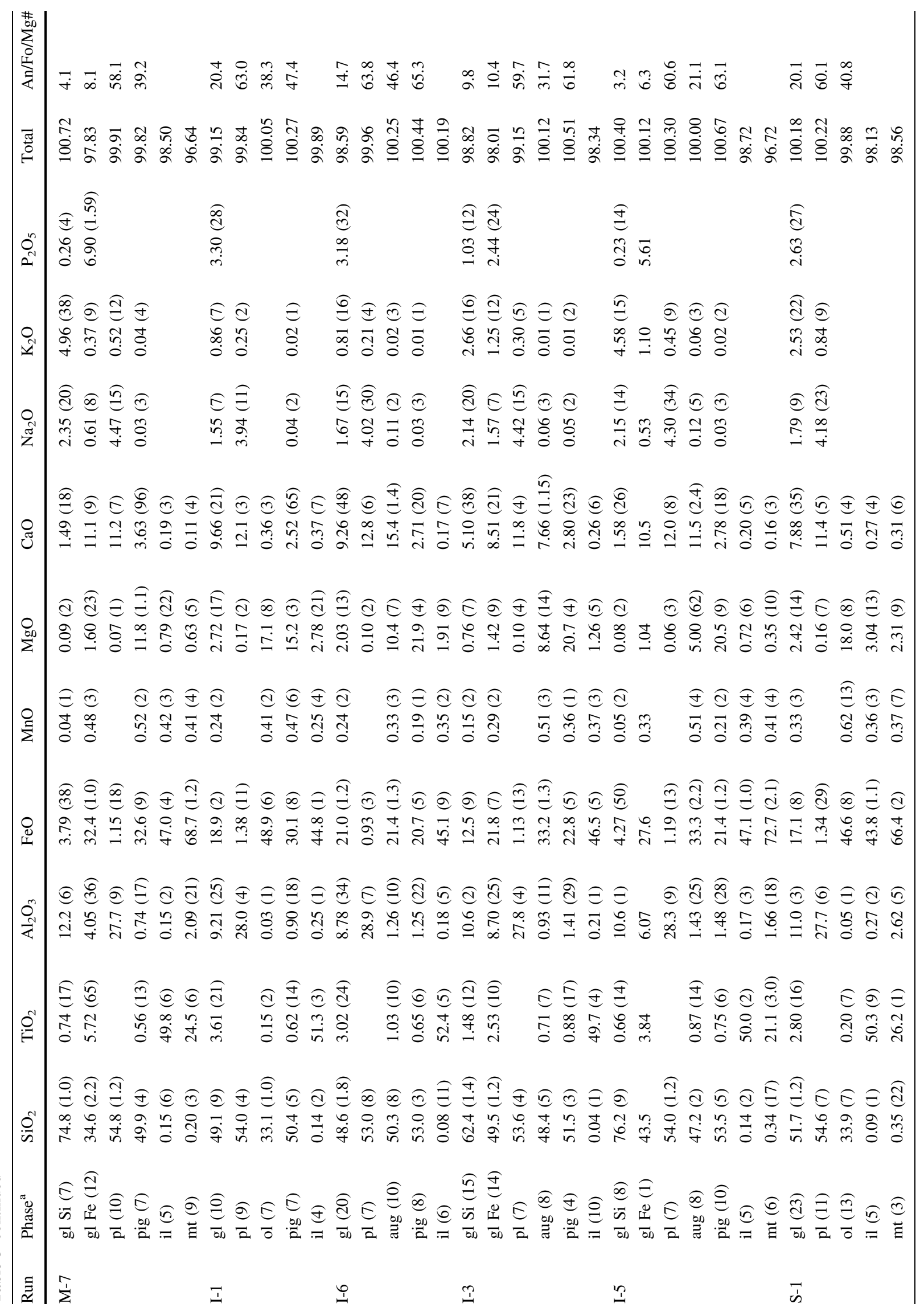




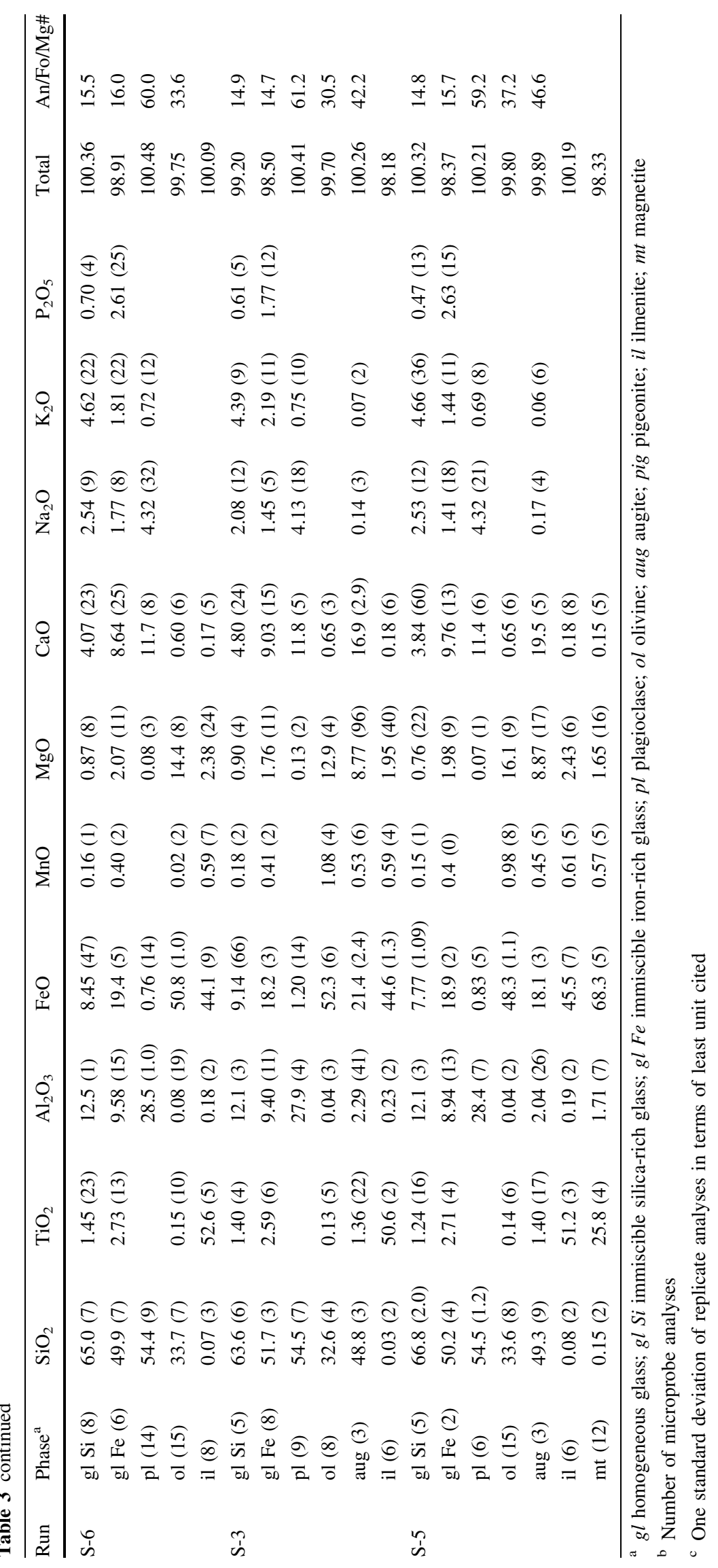




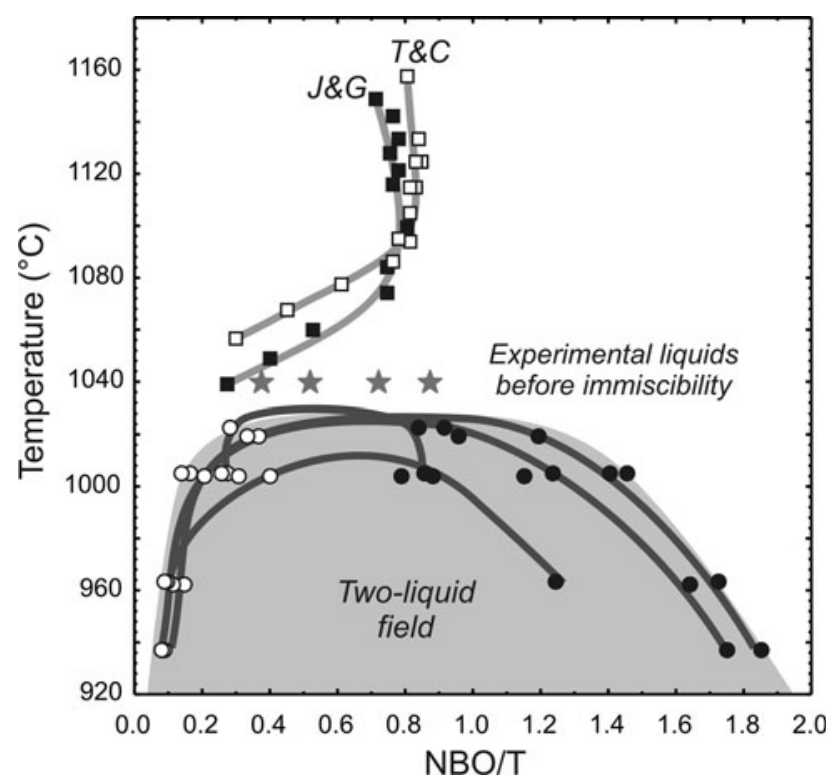

Fig. 4 Temperature as a function of the degree of polymerization $(\mathrm{NBO} / \mathrm{T})$ of experimental melts. NBO/T calculated assuming $\mathrm{T}=\mathrm{Si}+\mathrm{Al}+\mathrm{P}+\mathrm{Ti}$. Gray stars are homogeneous melts, black circles are Fe-rich immiscible melts, and white circles are Si-rich immiscible melts. The gray area represents the maximum compositional space of the two-liquid field. Each experiments for the liquid lines of descent of Toplis and Carroll (1995) (black squares) and Juster et al. (1989) (white square) are plotted

\section{Discussion}

The onset of silicate liquid immiscibility

It has been shown that the absence of intermediate silicate compounds on the liquidus and the occurrence of a field of liquid immiscibility are properties of highly polymerized liquids (e.g., Hess 1977; Bogaerts and Schmidt 2006; Schmidt et al. 2006). Silicate liquid immiscibility has already been experimentally shown to develop along the crystallization path of tholeiitic basalt (Dixon and Rutherford 1979; Martin and Kushiro 1991). Extreme iron enrichment from 19 to $26 \mathrm{wt} \%$ has been measured in homogeneous liquids at $10-20^{\circ} \mathrm{C}$ above the binodal, so this enrichment appeared a necessary condition for the onset of unmixing. A single experiment by Philpotts and Doyle (1983) reports an $\mathrm{FeO}_{\text {tot }}$ of $15.4 \mathrm{wt} \%\left(1,035^{\circ} \mathrm{C}\right.$, QFM) before the onset of immiscibility $10^{\circ} \mathrm{C}$ below.

Iron enrichment during tholeiitic differentiation is closely related to the concentration of alkalis. Enrichment above $22 \mathrm{wt} \% \mathrm{FeO}_{\text {tot }}$ in melts in equilibrium with the olivine + plagioclase + augite + pigeonite liquidus assemblage is observed only in alkali-poor liquids (Veksler 2009). Our experiments demonstrate that extreme iron enrichment is not necessary to reach the immiscibility field. Unmixing also develops along the liquid line of descent

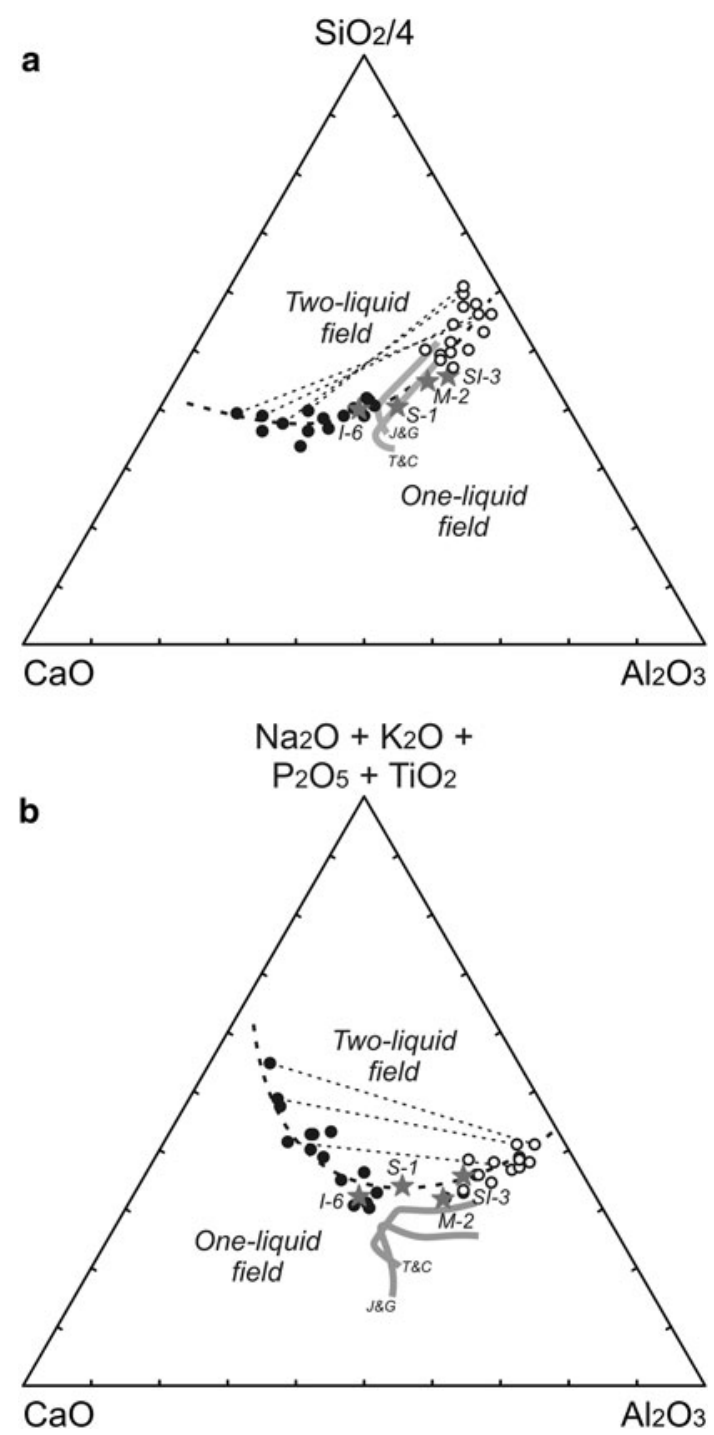

Fig. 5 Experimental glasses projected onto ternary diagrams with a $\mathrm{CaO}, \mathrm{Al}_{2} \mathrm{O}_{3}$, and $\mathrm{SiO}_{2} / 4$ and $\mathbf{b} \mathrm{CaO}, \mathrm{Al}_{2} \mathrm{O}_{3}$, and $\mathrm{Na}_{2} \mathrm{O}+\mathrm{K}_{2} \mathrm{O}+$ $\mathrm{P}_{2} \mathrm{O}_{5}+\mathrm{TiO}_{2}$. Gray curves labeled $\mathrm{T} \& \mathrm{C}$ and $\mathrm{J} \& \mathrm{G}$ are the liquid lines of descent of Toplis and Carroll (1995) and Juster et al. (1989), respectively. Gray stars are homogeneous melts before immiscibility (SI-3, M-2, S-1 and I-6), black circles are Fe-rich immiscible melts, and white circles are Si-rich immiscible melts. Tie lines join some immiscible pairs

during the iron depletion and silica enrichment that occurs after $\mathrm{Fe}-\mathrm{Ti}$ oxides appear in the crystallizing assemblage. This is illustrated by experiments on SI and M starting compositions, in which the homogeneous melts prior to immiscibility have $60.4 \mathrm{wt} \% \mathrm{SiO}_{2}-9.8 \mathrm{wt} \% \mathrm{FeO}_{\text {tot }}$ and $57.4 \mathrm{wt} \% \mathrm{SiO}_{2}-15.1 \mathrm{wt} \% \mathrm{FeO}_{\mathrm{tot}}$, respectively (Fig. 3).

Experimental liquids projected onto ternary diagrams with $\mathrm{CaO}, \mathrm{Al}_{2} \mathrm{O}_{3}$, and $\mathrm{SiO}_{2} / 4$ or $\mathrm{Na}_{2} \mathrm{O}+\mathrm{K}_{2} \mathrm{O}+\mathrm{P}_{2} \mathrm{O}_{5}+$ $\mathrm{TiO}_{2}$ show the importance of variations in bulk composition on the onset of immiscibility and on the width of the twoliquid field (Fig. 5). Liquid compositions before immiscibility also influence the separation of the immiscible pairs. 
The alignment of immiscible melts defines the binodal curves that separate the one-liquid from the two-liquid fields. The composition of the homogeneous melt along the liquid line of descent at the onset of immiscibility defines the width of the solvus (see Fig. 2). Liquids that reach the binodal after significant silica enrichment (compositions SI-3 and M-2), or after iron enrichment (composition I-6), produce immiscible pairs with extensive compositional separation, which enables to separate easily into two melts. The occurrence of diffuse immiscibility for compositions $\mathrm{S}$ is particularly informative, because that composition reaches immiscibility near the closure of the binodal and produces immiscible pairs with narrow compositional separation.

The compositions of immiscible pairs define a locus between which immiscibility develops. Any composition that plots on the mixing trend between the equilibrium immiscible pairs would unmix, the proportion of the two liquids being defined by the lever rule. We use this property to propose compositional criteria for the development of immiscibility. The Si-rich and Fe-rich liquids from hightemperature $\left(1,000-1,020^{\circ} \mathrm{C}\right)$ immiscible pairs (experiments SI-13, M-9, I-3, and S-6) can be mixed in appropriate proportions to obtain liquid compositions at 50, 55, and $60 \mathrm{wt} \%$ $\mathrm{SiO}_{2}$. These calculated bulk compositions are immiscible and would not exist in nature as homogeneous melts; they define the limit between the single-liquid and the two-liquid fields. The $\mathrm{FeO}_{\text {tot }}$ of these calculated compositions is plotted as a function of $\mathrm{Na}_{2} \mathrm{O}+\mathrm{K}_{2} \mathrm{O}+\mathrm{P}_{2} \mathrm{O}_{5}$ and $\mathrm{Na}_{2} \mathrm{O}+\mathrm{K}_{2} \mathrm{O}+$ $\mathrm{P}_{2} \mathrm{O}_{5}+\mathrm{TiO}_{2}$ (Fig. 6a-b). Two diagrams are used, with and without $\mathrm{TiO}_{2}$, because, although $\mathrm{TiO}_{2}$ is important for the development of immiscibility (Visser and Koster van Groos 1979b; Bogaerts and Schmidt 2006), our experiments do not discriminate its role as they all have similar $\mathrm{TiO}_{2}$ content at the onset of immiscibility. Alkalis reduce the liquidus temperature, as well as $\mathrm{P}_{2} \mathrm{O}_{5}$ and $\mathrm{TiO}_{2}$, which also expand the immiscibility field (Bogaerts and Schmidt 2006). This favors the intersection between the liquidus and the binodal. Figure $6 \mathrm{a}-\mathrm{b}$ shows that iron enrichment must be higher at lower $\mathrm{SiO}_{2}$ for immiscibility to develop. High $\mathrm{Na}_{2} \mathrm{O}+$ $\mathrm{K}_{2} \mathrm{O}+\mathrm{P}_{2} \mathrm{O}_{5} \pm \mathrm{TiO}_{2}$ contents therefore promote unmixing at lower $\mathrm{FeO}_{\text {tot }}$.

These high-temperature immiscible liquids obtained from the four starting compositions are in equilibrium with various liquidus assemblages. SI- 13 (at $1,020^{\circ} \mathrm{C}$ ) is saturated with plagioclase $\left(\mathrm{An}_{36.7}\right)$, olivine $\left(\mathrm{Fo}_{43.2}\right)$, augite, pigeonite, ilmenite, magnetite, and whitlockite. This is the same assemblage as that observed in cumulates crystallized from immiscible liquids in the Sept Iles layered intrusion (Namur et al. 2010; Charlier et al. 2011). The Mull composition $\left(\mathrm{M}-9 ; 1,020^{\circ} \mathrm{C}\right)$ has plagioclase $\left(\mathrm{An}_{60.4}\right)$, olivine $\left(\mathrm{Fo}_{33.9}\right)$, pigeonite, ilmenite, and magnetite on liquidus. I-3 $\left(1,005^{\circ} \mathrm{C}\right)$ contains plagioclase $\left(\mathrm{An}_{59.7}\right)$, augite, ilmenite,
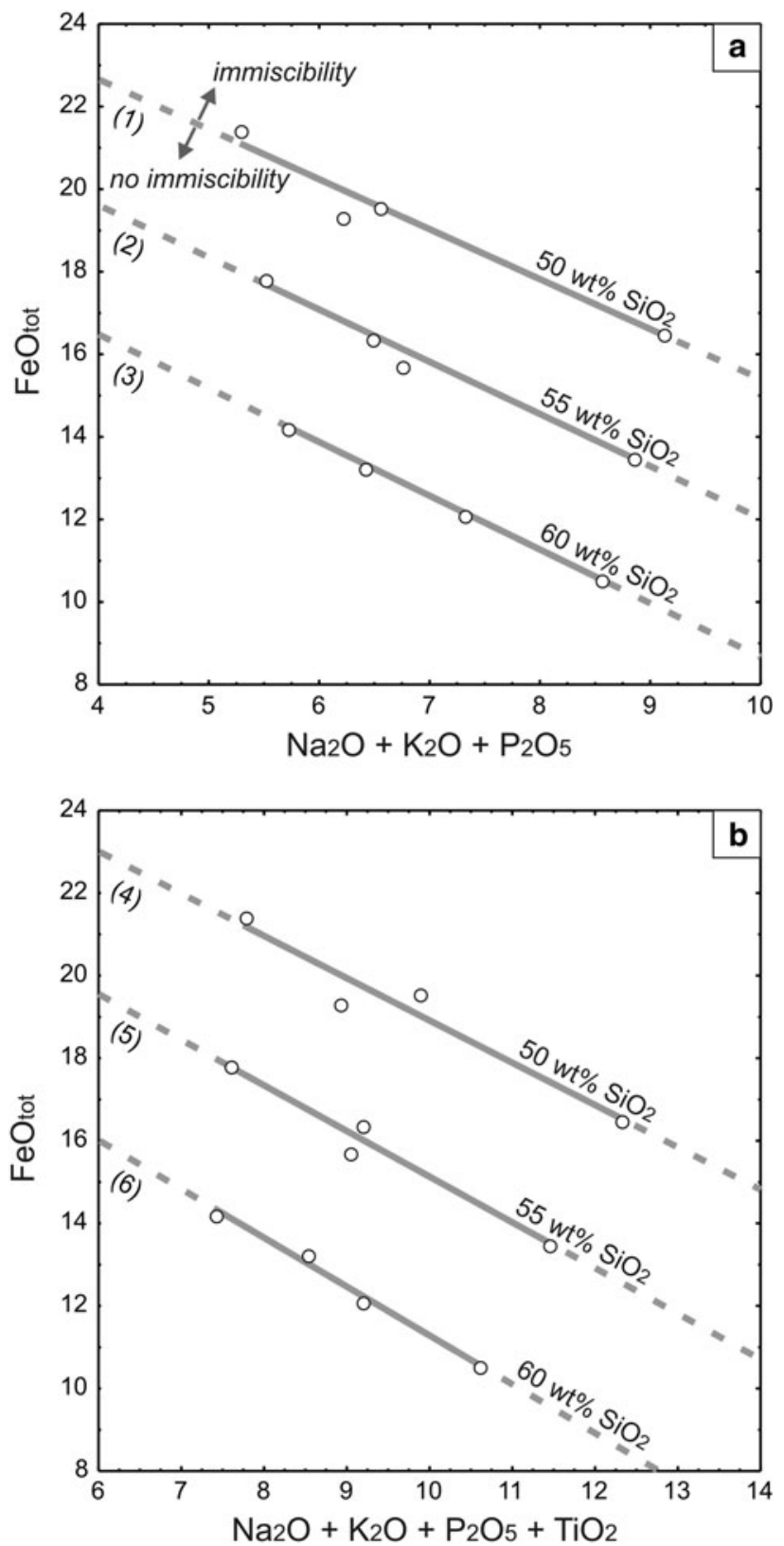

Fig. 6 Compositional criteria for the development of silicate liquid immiscibility along tholeiitic liquid lines of descent. Immiscible pairs SI-13, M-9, I-3, and S-6 are mixed in appropriate proportions to obtain liquid compositions at 50,55 , and $60 \mathrm{wt} \% \mathrm{SiO}_{2}$ (white circles), plotted in a $\mathrm{FeO}_{\text {tot }}$ versus $\mathrm{Na}_{2} \mathrm{O}+\mathrm{K}_{2} \mathrm{O}+\mathrm{P}_{2} \mathrm{O}_{5}(\mathrm{wt} \%)$ and $\mathbf{b} \mathrm{FeO}_{\text {tot }}$ versus $\mathrm{Na}_{2} \mathrm{O}+\mathrm{K}_{2} \mathrm{O}+\mathrm{P}_{2} \mathrm{O}_{5} \pm \mathrm{TiO}_{2}$ (wt\%). Immiscibility develops when liquids of a given $\mathrm{SiO}_{2}$ content plot above the appropriate linear trend (gray lines), the dashed gray lines being the extrapolation of the experimental dataset. Regressions are $y=-1.2165 x+27.463$ (line 1); $y=-1.2722 x+24.63$ (2); $y=-1.2959 x+21.584$ (3); $y=-1.0246 x+29.165 \quad(4) ; \quad y=-1.1072 x+26.181 \quad(5) ; \quad y=$ $-1.1833 x+23.072(6)$

whitlockite, and quartz, while S-6 $\left(1,023^{\circ} \mathrm{C}\right)$ crystallized plagioclase $\left(\mathrm{An}_{60.0}\right)$, olivine $\left(\mathrm{Fo}_{33.6}\right)$, ilmenite, and whitlockite. There is thus a balance between the anorthite 
content in plagioclase and the Mg-numbers of olivine and pyroxenes. Immiscibility can develop at higher anorthite content if the $\mathrm{Mg}$-number is lower (high $\mathrm{FeO}_{\text {tot }}$ in the melt), while ferromagnesian minerals can be more primitive (higher Mg-numbers) if the alkali content in the melt is higher (lower anorthite in plagioclase).

Magma compositions and liquidus assemblages at the start of silicate liquid immiscibility can therefore vary broadly. However, the temperature at which the liquidus crosses the binodal seems to be restricted to the $1,000-1,020^{\circ} \mathrm{C}$ range. Our results do not support hightemperature immiscibility $\left(>1,100^{\circ} \mathrm{C}\right)$ as proposed by Veksler et al. $(2007,2008)$ and challenged by Philpotts (2008) and Morse (2008). We concur with Veksler et al. (2010) that very low interfacial tension between the less compositionally contrasting ferrobasaltic and rhyolitic melts is responsible for easy nucleation of immiscible liquid droplets and very slow coarsening. This is observed in our experiments S-6, S-3, and S-5, which show the narrower compositional gap between the immiscible pairs. However, even for these compositions, two discrete liquids are clearly identifiable. A convincing proof of immiscibility at higher temperatures would be to obtain two liquids from our experiments at $1,040-1,060^{\circ} \mathrm{C}$ after centrifugation. These two liquids should be closer in composition to each other than the two liquids obtained at $1,020^{\circ} \mathrm{C}$, which were separated in static conditions.

\section{Evolution trends and sub-liquidus binodal}

In AFM diagrams (Fig. 7), the two-liquid field defined by the compositions of immiscible pairs covers a wide area, apparently reached by the two classic experimental liquid lines of descent for ferrobasalts of Juster et al. (1989) and Toplis and Carroll (1995). However, although these liquid lines of descent cross tie lines between immiscible melts close to their iron maxima, the liquidus temperature of these compositions is higher than that of the binodal curves. This is clearly illustrated in Fig. 4.

Because the tie lines between immiscible melts occupy the same multicomponent compositional space compared to that of magmatic evolution trends (Fig. 3), tholeiitic liquids will inevitably reach the part of compositional space required for immiscibility. The other condition for the onset of immiscibility is that the liquidus temperature crosses the sub-liquidus binodal during differentiation, a condition that is not satisfied in the studies of Juster et al. (1989) and Toplis and Carroll (1995). Below, we discuss compositional criteria and crystallization conditions that have an effect on evolution trends, liquidus temperature, and size of the two-liquid field. The objective is to identify favorable crystallization conditions for the development of immiscibility.

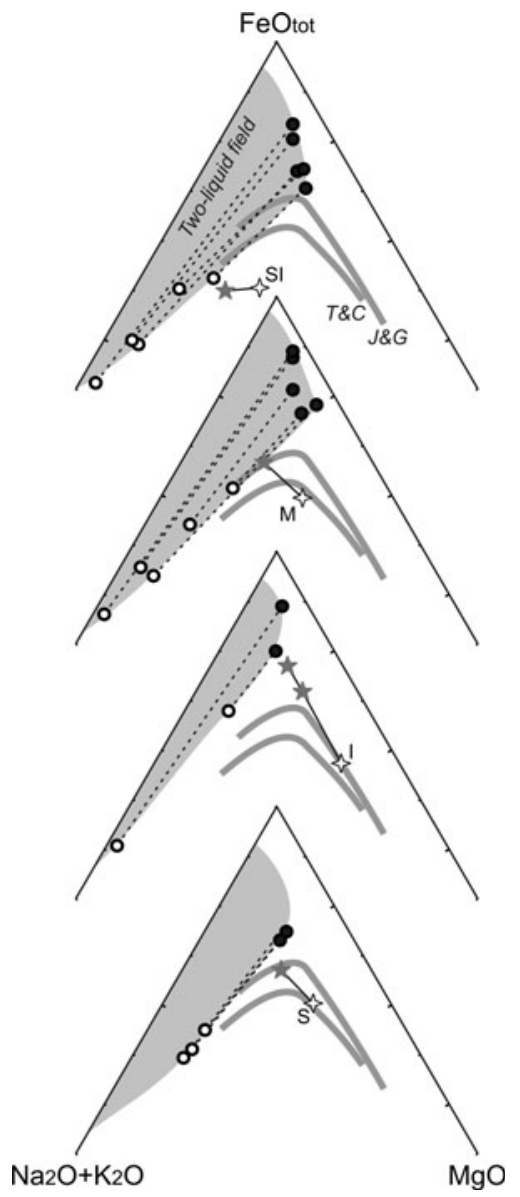

Fig. 7 Experimental glasses plotted in AFM diagrams. Same legend as in Fig. 3. The gray areas are the interpreted two-liquid stability fields

The effect of phosphorous

Phosphorous behaves as an incompatible element during much of basalt differentiation and may reach 2-3 wt $\%$ $\mathrm{P}_{2} \mathrm{O}_{5}$ in ferrobasalts before apatite saturation (Harrison and Watson 1984). Phosphorous contents of evolved tholeiitic basalt are usually 1-1.5 wt $\% \mathrm{P}_{2} \mathrm{O}_{5}$ (Kerr et al. 1999; Namur et al. 2011) and may reach 2.5-3.5 wt \% $\mathrm{P}_{2} \mathrm{O}_{5}$ at Craters of the Moon (Leeman et al. 1976; Putirka et al. 2009). This range is covered by our experimental liquids prior to immiscibility $\left(0.99-3.18 \mathrm{wt} \% \mathrm{P}_{2} \mathrm{O}_{5}\right)$.

A detailed study of the role of phosphorous in basalt crystallization by Toplis et al. (1994) shows its importance on phase equilibria, with direct implications for the development of immiscibility. Phosphorous promotes iron enrichment during differentiation because it destabilizes magnetite and increases the modal plagioclase/pyroxene ratio. Phosphorous also depresses the liquidus temperature, and therefore, as well as expanding the two-liquid field (Bogaerts and Schmidt 2006; Ryerson and Hess 1978; 
Visser and Koster van Groos 1979b; Watson 1976), it promotes the development of a sub-liquidus binodal. Although this element has little influence on primitive compositions, its role is significant in evolved tholeiitic basalts and is probably the main factor responsible for the absence of immiscibility in experimental studies on the differentiation of ferrobasalts by Juster et al. (1989) and Toplis and Carroll (1995), who did not incorporate $\mathrm{P}_{2} \mathrm{O}_{5}$ in their starting material.

The effect of crystallization pressure

The main effect of pressure on phase equilibria of tholeiitic basalts is to expand the augite stability field, reducing the amount of cotectic plagioclase in the crystallizing assemblage (Grove and Baker 1984; Grove et al. 1992; Villiger et al. 2004, 2007). At low pressure, the crystallization sequence is olivine followed by plagioclase (ca. $75 \%$ plagioclase, $25 \%$ olivine) and then by augite (58\% plagioclase, 25\% augite, 17\% olivine; Grove and Bryan 1983). Plagioclase thus dominates the assemblage and promotes iron enrichment. With increasing pressure, olivine, augite, and plagioclase crystallizes in closer mass proportions, inhibiting high iron enrichment in the melt. Villiger et al. (2007) report that at $1.0 \mathrm{GPa}, \mathrm{FeO}_{\text {tot }}$ starts to decrease after it reaches a maximum at $<10 \mathrm{wt} \%$, whereas the maximum is $16.7 \mathrm{wt} \%$ at $0.7 \mathrm{GPa}$. They note that higher $\mathrm{FeO}_{\text {tot }}$ at a given $\mathrm{Mg}$-number in the parental composition promotes steeper iron enrichment. Moreover, because plagioclase saturates earlier at low pressure, $\mathrm{TiO}_{2}$ increases more rapidly before the onset of ilmenite crystallization. Because iron and titanium enrichments lead to the development of immiscibility, crystallization of tholeiitic basalt at low pressure favors this process.

Although increasing pressure widens the two-melt field, it also raises the liquidus temperature of the crystalline phases. Its overall effect is therefore to reduce the composition and temperature range of the liquid immiscibility in the system $\mathrm{K}_{2} \mathrm{O}-\mathrm{FeO}-\mathrm{Al}_{2} \mathrm{O}_{3}-\mathrm{SiO}_{2}$ (Visser and Koster van Groos 1979c). This effect is also observed in binary systems (Hudon et al. 2004).

\section{Equilibrium versus fractional crystallization}

Toplis and Carroll (1996) calculated that maximum iron enrichment is produced by fractional crystallization rather than equilibrium crystallization of ferrobasalts. The difference is tiny, but in a system which follows a $\mathrm{T}-f \mathrm{O}_{2}$ path parallel to the QFM buffer under conditions open to oxygen, the liquid line of descent reaches $19 \mathrm{wt} \% \mathrm{FeO}_{\text {tot }}$ for fractional crystallization compared to $18 \mathrm{wt} \%$ for equilibrium crystallization (Fig. 8a). Similar results are obtained by Thy et al. (2006), who also point out that fractional crystallization

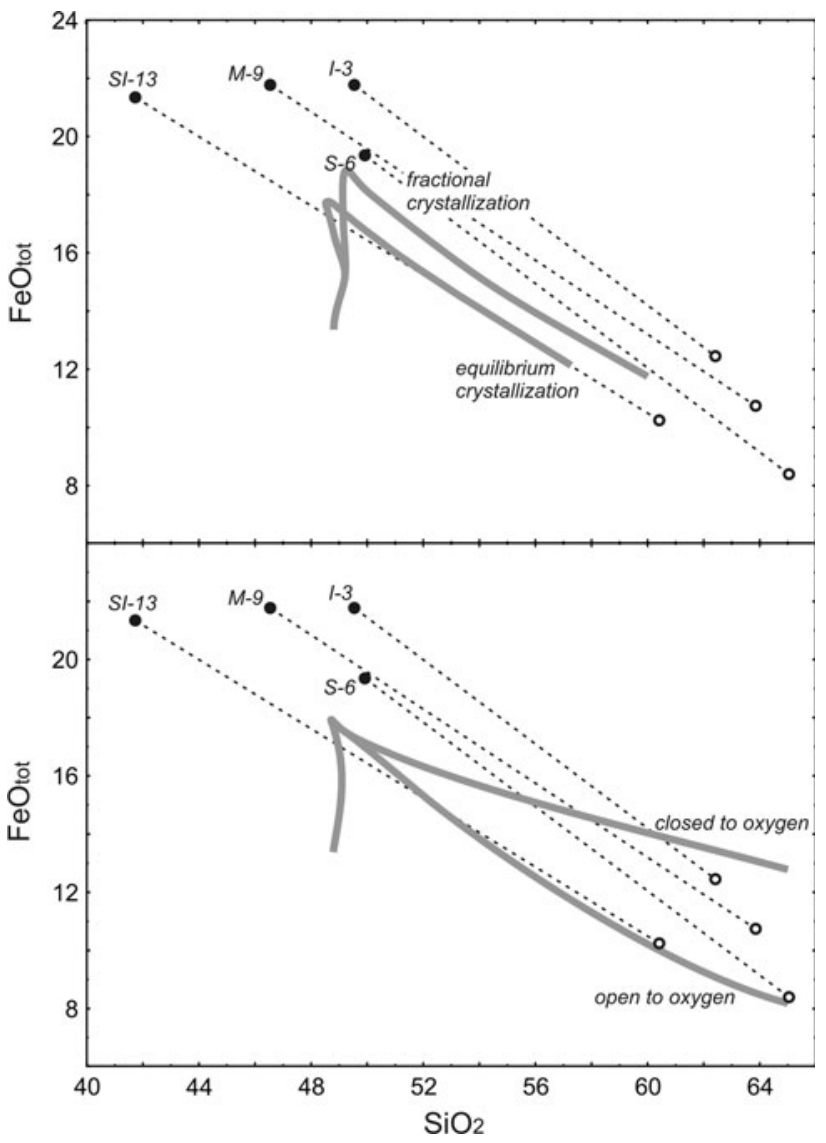

Fig. 8 Covariation of iron and silica for experimental glasses at the onset of immiscibility compared to liquid lines of descent obtained by Toplis and Carroll (1996) for an estimated parental of the Skaergaard intrusion (gray lines) for a. Fractional versus equilibrium crystallization under conditions open to oxygen and b. Equilibrium crystallization closed and open to oxygen. Black circles are Fe-rich immiscible melts and white circles are Si-rich immiscible melts. Tie lines join immiscible pairs

produces relative $\mathrm{Na}_{2} \mathrm{O}$ enrichment and that equilibrium crystallization yields a slightly higher solid fraction at similar model temperatures. $\mathrm{CaO}, \mathrm{MgO}$, and $\mathrm{Al}_{2} \mathrm{O}_{3}$ contents also decrease more rapidly with temperature during fractional crystallization (Ghiorso 1997; Toplis and Carroll 1996).

The compositional evolution of tholeiitic basalt produced by fractional crystallization favors the development of immiscibility. High $\mathrm{MgO}$ and $\mathrm{CaO}$ inhibit unmixing, mainly by increasing the liquidus temperature (Bogaerts and Schmidt 2006). The structural role of $\mathrm{Al}_{2} \mathrm{O}_{3}$ has been clearly identified by Wood and Hess (1980), and our data support that the immiscibility field widens at low $\mathrm{Al}_{2} \mathrm{O}_{3}$ contents (Fig. 3,5). The effect of fractional crystallization in promoting immiscibility also explains why immiscibility was not observed in experiments by Juster et al. (1989) and Toplis and Carroll (1995), which reached silica-rich compositions (64-67 wt\% $\mathrm{SiO}_{2}$ ) by temperatures in the range $1,040-1,057^{\circ} \mathrm{C}$. In addition to omitting phosphorous, which would depress the liquidus 
Fig. 9 Schematic illustration of the effect of magma mixing in promoting or inhibiting the potential development of immiscibility along the tholeiitic liquid line of descent (gray lines). a-b Mixing between the parental basalt and a differentiated $\mathrm{Fe}-\mathrm{Ti}-\mathrm{P}$-rich ferrobasalt producing an hybrid on the way to immiscibility; c-d Mixing between the parental basalt and an evolved silicic composition producing an hybrid far from the immiscibility field
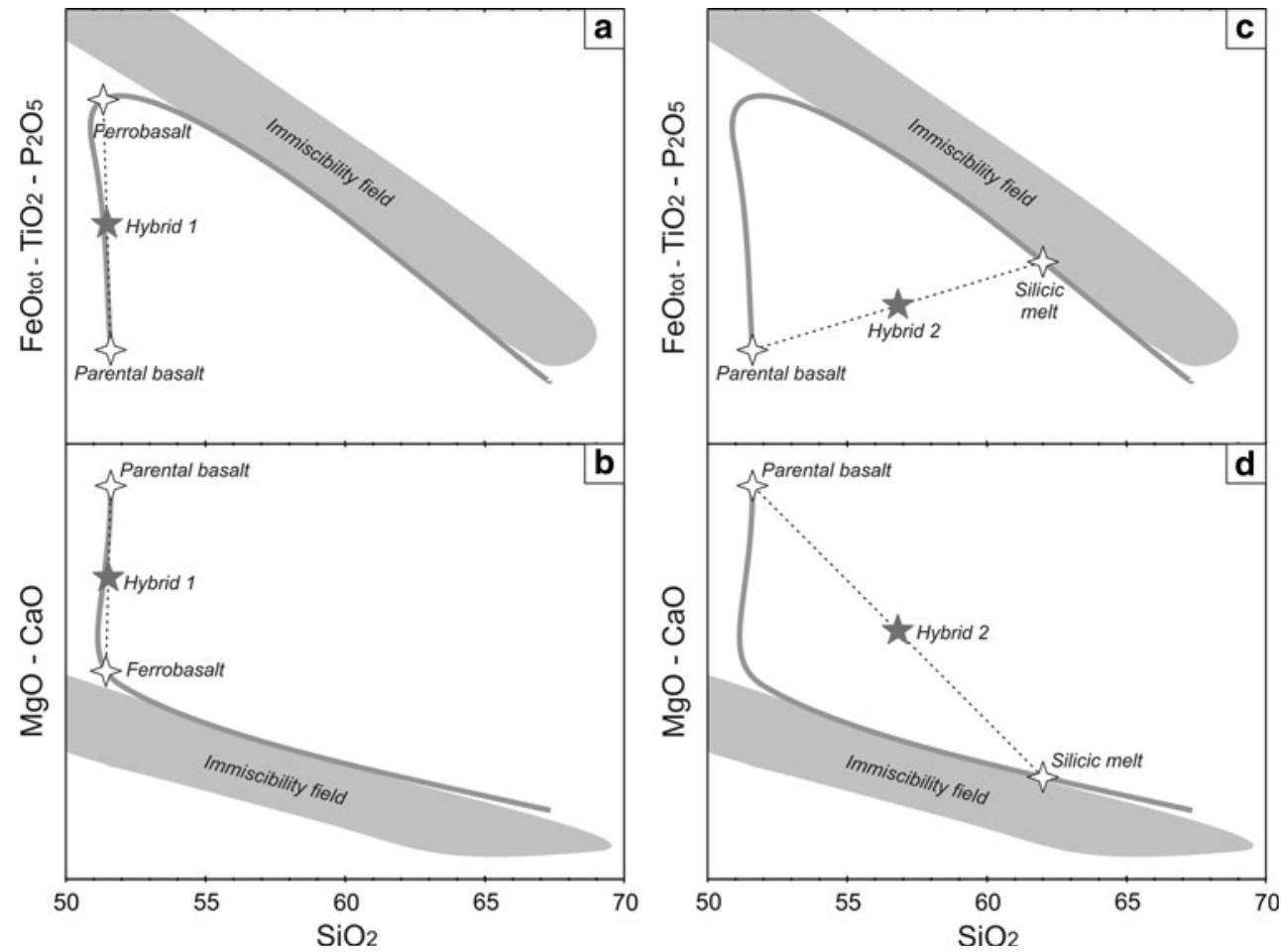

temperature, these experiments recreated equilibrium crystallization conditions. Compositional evolution in natural systems, usually considered to result from fractional crystallization, will produce suites of liquids more likely to develop immiscibility. This is illustrated by the Skaergaard case: immiscibility has been thoughtfully described in natural rocks (McBirney 1975; Jakobsen et al. 2005, 2011; Holness et al. 2011; Humphreys 2011) but not reproduced during experiments on the parental magma composition (Toplis and Carroll 1995; Thy et al. 2006).

The role of oxygen fugacity

Oxygen fugacity $\left(f \mathrm{O}_{2}\right)$ has a significant influence on the two-melt field. Naslund (1983) has shown that high $\mathrm{Fe}_{2} \mathrm{O}_{3} /$ $\mathrm{FeO}$ widens the two-liquid field and increases the upper temperature limit of immiscibility in the system $\mathrm{KAlSi}_{3} \mathrm{O}_{8}$ $\mathrm{FeO}-\mathrm{Fe}_{2} \mathrm{O}_{3}-\mathrm{SiO}_{2}$. However, $f \mathrm{O}_{2}$ also influences the stability and appearance temperature of $\mathrm{Fe}-\mathrm{Ti}$ oxides (Toplis and Carroll 1995). During the differentiation of ferrobasalts, magnetite is the first $\mathrm{Fe}$-Ti oxide to appear on liquidus above the QFM buffer. Its liquidus temperature increases by ca. $30^{\circ} \mathrm{C}$ per $\log f \mathrm{O}_{2}$ unit. High $f \mathrm{O}_{2}$ thus promotes early crystallization of magnetite which prevents iron enrichment. The immiscibility widening caused by high $f \mathrm{O}_{2}$ is strongly counteracted by the stabilization of magnetite and resultant iron depletion. Experiments by Philpotts and Doyle (1983) on a tholeiitic basalt show stable immiscibility on magnetite-wüstite and QFM buffers below $1,018^{\circ} \mathrm{C}$, while abundant crystallization of magnetite at NNO terminates the immiscibility field.

Differentiation under conditions closed to oxygen favors immiscibility compared to conditions open to oxygen (Fig. 8b; Toplis and Carroll 1996). Although both conditions reach similar maximum iron contents, iron depletion is more pronounced under conditions open to oxygen, due to extensive magnetite crystallization. Consequently, if the two-liquid field is not reached during the iron enrichment phase, the liquid line of descent will cross the binodal more readily during evolution when closed to oxygen.

The effect of magma mixing

The effect of magma mixing can be illustrated by two extreme scenarios (Fig. 9). Mixing between the parental basaltic melt and a ferrobasalt with maximum enrichment in $\mathrm{Fe}-\mathrm{Ti}$ will produce a hybrid, with a similar $\mathrm{SiO}_{2}$ content, that seems to lie on the liquid line of descent of the primitive basalt (hybrid 1; Fig. 9a, b). However, the liquid produced by hybridization does not correspond to any liquid on the normal evolution trend of the primitive basalt. Indeed, the effect for each element depends on the relative factor of enrichment or depletion during this differentiation interval, such that this mixing actually changes elemental ratios. Highly incompatible elements, such as $\mathrm{P}_{2} \mathrm{O}_{5}, \mathrm{~K}_{2} \mathrm{O}$ and, to a lesser extent, $\mathrm{Na}_{2} \mathrm{O}$, will be enriched by mixing because their enrichments in residual liquids are higher for a similar degree of evolution 
(compared to $\mathrm{Ti}$ or $\mathrm{Fe}$ ). Repeated mixing events will produce hybrids with increasing $\mathrm{P}_{2} \mathrm{O}_{5} / \mathrm{MgO}, \mathrm{P}_{2} \mathrm{O}_{5} / \mathrm{CaO}$, and alkali content at broadly constant $\mathrm{SiO}_{2}$, thus expanding the size of the immiscibility field and reducing the liquidus temperature.

On the contrary, mixing between primitive basalts and evolved silica enriched and Fe-Ti-P-depleted compositions produced hybrids far from the silicate immiscibility field (hybrid 2; Fig. 9c, d). This type of mixing explains the occurrence of phosphorous-depleted intermediate compositions in tholeiitic series (Juster et al. 1989). Assimilation of 'granitic' material would produce the same effect.

The potential effect of water

The amount of water in tholeiitic basalts is usually considered to be low. However, during late-stage differentiation, water becomes significant due to its incompatible behavior. Primitive MORB basalts (10 wt $\% \mathrm{MgO}$ ) have ca. $0.1 \mathrm{wt} \% \mathrm{H}_{2} \mathrm{O}$, compared with $0.4-0.6 \mathrm{wt} \% \mathrm{H}_{2} \mathrm{O}$ at 5-6 wt\% MgO (Danyushevsky 2001). In this study, starting compositions have 2.7-4.5 wt\% MgO, so water contents up to $1-2 \mathrm{wt} \%$ are likely in natural systems. Indeed, liquid compositions with a $1,060^{\circ} \mathrm{C}$ liquidus temperature are produced by fractional crystallization of primitive mantlederived tholeiitic basalt after $>95 \mathrm{wt} \%$ of solid-phase subtraction (Villiger et al. 2007), thus enriching the liquid in incompatible water by a factor of $>20$.

The biggest effect of water on the phase equilibria of basalts is to suppress plagioclase crystallization relative to olivine and clinopyroxene and to promote early crystallization of Fe-Ti oxides (Sisson and Grove 1993; Berndt et al. 2005; Botcharnikov et al. 2008). Water thus precludes significant $\mathrm{Fe}$ enrichment during differentiation and inhibits the immiscibility process by shifting the liquid line of descent from a tholeiitic to a calc-alkaline trend. This probably explains why silicate liquid immiscibility has never been convincingly described in calc-alkaline provinces.

Even if the liquid line of descent might leave the twoliquid field by simple fractional crystallization and compositional evolution of the bulk liquid (Fig. 10a), $\mathrm{H}_{2} \mathrm{O}$ might play a role due to its importance on the binodal. The critical temperature of the binodal might move below the liquid line of descent with decreasing temperature and water enrichment, which would lead the system to evolve as a single melt phase. This has been observed in carbonatitic systems. Koster Van Groos and Wyllie (1968) noted a size reduction of the two-liquid field with water in the albite- $\mathrm{Na}_{2} \mathrm{CO}_{3}$ system. This was further supported in experiments by Lee and Wyllie (1994), who show that the high-temperature silicate-carbonate miscibility gap closes with decreasing temperature in the presence of $\mathrm{H}_{2} \mathrm{O}$.
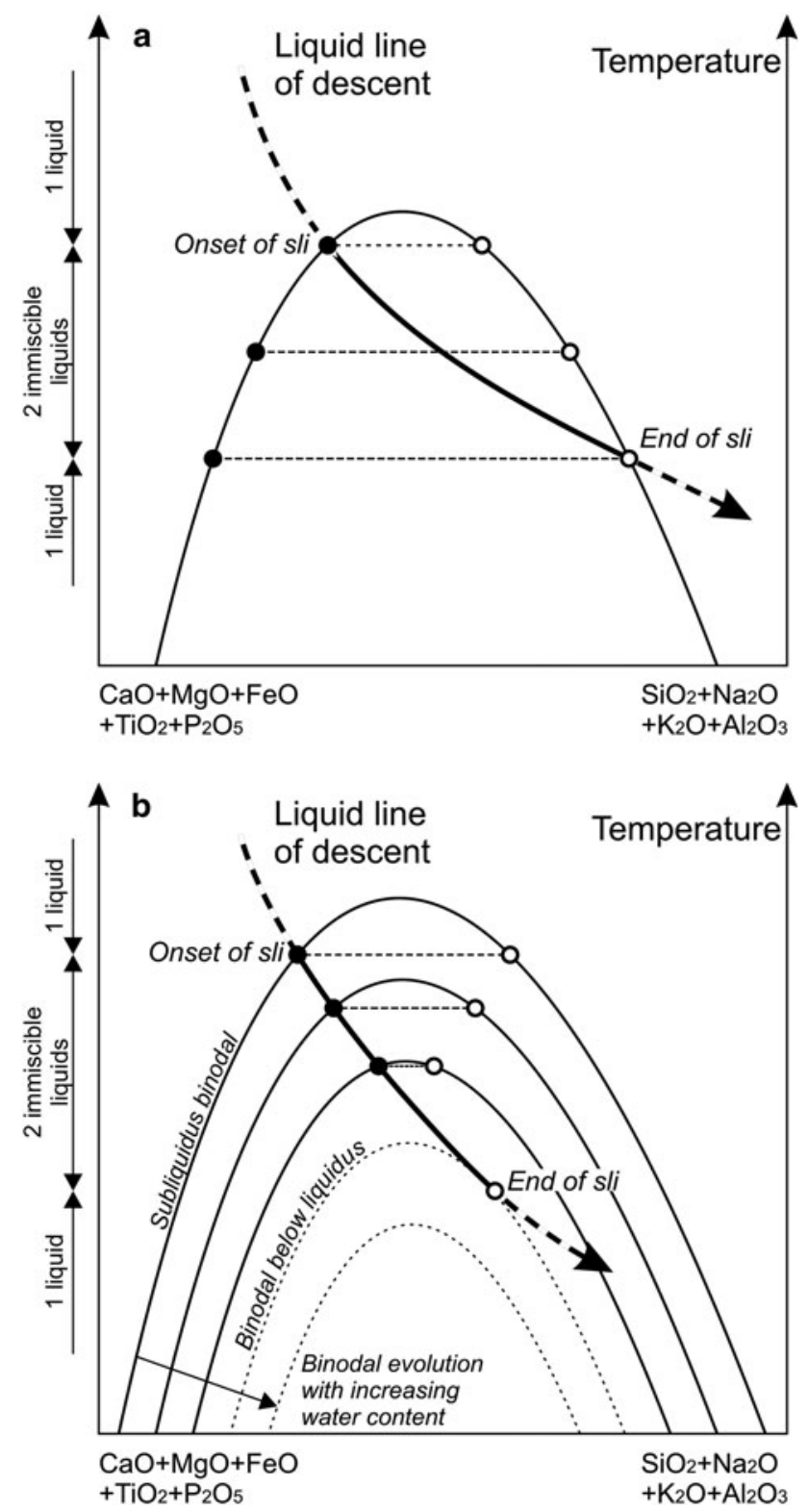

Fig. 10 Schematic illustration of the evolution of the liquid line of descent through a two-liquid field. a Evolution of the trend with a single binodal; the onset and end of silicate liquid immiscibility simply result from the differentiation of the bulk liquid. b Potential effect of increasing water content during differentiation of tholeiitic basalt. The size and temperature of the binodal curves decrease differentiation so that immiscible liquids become closer in composition. The crest of the binodal ultimately passes below the liquid line of descent leading to further evolution as a single-liquid phase

The effect on the binodal of increasing water content during differentiation is schematically illustrated in Fig. 10b. Water is responsible for decreasing the temperature and size of the binodal. Although water also decreases the liquidus temperature (Médard and Grove 2008), its effect seems more important on the binodal, as shown in carbonatitic systems (Lee and Wyllie 1994). With differentiation, the composition of immiscible liquids converges. 
This convergence of immiscible liquid compositions has been shown to occur in the Sept Iles layered intrusion (Charlier et al. 2011). At a certain point, the binodal shifts below the liquid line of descent and immiscibility ends. Note that because the two liquids become very close in composition, they might not be able to segregate before the actual binodal-liquidus inversion (Veksler et al. 2010).

\section{Conclusions}

Tholeiitic series are expected to reach silicate liquid immiscibility during differentiation from basalt to rhyolite. Although experimental melts produced in this study have a large compositional range, immiscibility is reached between 1,000 and $1,020^{\circ} \mathrm{C}$ for the four starting materials. The liquid line of descent can intersect a sub-liquidus binodal surface close to the maximum iron enrichment or after silica enrichment and iron depletion caused by $\mathrm{Fe}-\mathrm{Ti}$ oxide saturation. High phosphorous, alkali, and titanium contents promote unmixing at lower iron content (Fig. 6). Anhydrous low-pressure fractional crystallization under conditions closed to oxygen promotes the potential development of immiscibility during differentiation. Magma mixing between primitive basalt and Fe-Ti-P-rich ferrobasalts promotes unmixing because it is responsible for phosphorous and alkali enrichment at constant silica content. Pressure and water promotes early iron depletion, driving the liquid of descent far from the immiscibility field. Magma mixing with evolved silicic compositions produces the same effect.

Acknowledgments $\mathrm{BC}$ acknowledges support by a Marie Curie International Outgoing Fellowship within the 7th European Community Framework Programme. TLG acknowledges support from NSF Grant EAR 1118598. Comments by A. Andrews, J.C. Duchesne, B. Mandler, and O. Namur have been greatly appreciated. Reviews by R. Botcharnikov and I. Veksler have improved the manuscript.

\section{References}

Armstrong JT (1995) Citzaf-a package of correction programs for the quantitative electron microbeam X-ray analysis of thick polished materials, thin-films, and particles. Microbeam Anal 4:177-200

Berndt J, Koepke J, Holtz F (2005) An experimental investigation of the influence of water and oxygen fugacity on differentiation of MORB at $200 \mathrm{MPa}$. J Petrol 46:135-167

Bogaerts M, Schmidt MW (2006) Experiments on silicate melt immiscibility in the system $\mathrm{Fe}_{2} \mathrm{SiO}_{4}-\mathrm{KAlSi}_{3} \mathrm{O}_{8}-\mathrm{SiO}_{2}-\mathrm{CaO}-\mathrm{MgO}-$ $\mathrm{TiO}_{2}-\mathrm{P}_{2} \mathrm{O}_{5}$ and implications for natural magmas. Contrib Mineral Petrol 152:257-274

Botcharnikov RE, Almeev RR, Koepke J, Holtz F (2008) Phase relations and liquid lines of descent in hydrous ferrobasaltimplications for the Skaergaard intrusion and Columbia River flood basalts. J Petrol 49:1687-1727
Brooks CK, Nielsen TFD (1978) Early stages in the differentiation of the Skaergaard magma as revealed by a closely related suite of dike rocks. Lithos 11:1-14

Carmichael ISE (1964) The petrology of Thingmuli, a tertiary volcano in eastern Iceland. J Petrol 5:435-460

Charlier B, Namur O, Toplis MJ, Schiano P, Cluzel N, Higgins MD, Vander Auwera J (2011) Large-scale silicate liquid immiscibility during differentiation of tholeiitic basalt to granite and the origin of the Daly gap. Geology 39:907-910

Danyushevsky LV (2001) The effect of small amounts of $\mathrm{H}_{2} \mathrm{O}$ on crystallisation of mid-ocean ridge and backarc basin magmas. J Volcanol Geotherm Res 110:265-280

Dixon S, Rutherford MJ (1979) Plagiogranites as late-stage immiscible liquids in ophiolite and mid-ocean ridge suites: an experimental study. Earth Planet Sci Lett 45:45-60

Freestone IC, Powell R (1983) The low temperature field of liquid immiscibility in the system $\mathrm{K}_{2} \mathrm{O}-\mathrm{Al}_{2} \mathrm{O}_{3}-\mathrm{FeO}-\mathrm{SiO}_{2}$ with special reference to the join fayalite-leucite-silica. Contrib Mineral Petrol 82:291-299

Ghiorso MS (1997) Thermodynamic models of igneous processes. Annu Rev Earth Planet Sci 25:221-241

Grove TL (1981) Use of FePt alloys to eliminate the iron loss problem in 1 atmosphere gas mixing experiments: Theoretical and practical considerations. Contrib Mineral Petrol 78:298-304

Grove TL, Baker MB (1984) Phase equilibrium controls on the tholeiitic versus calc-alkaline differentiation trends. J Geophys Res 89:3253-3274

Grove TL, Bryan WB (1983) Fractionation of pyroxene-phyric MORB at low pressure: an experimental study. Contrib Mineral Petrol 84:293-309

Grove TL, Kinzler RJ, Bryan WB (1992) Fractionation of midocean ridge basalt (MORB). In: Morgan JP, Blackman DK, Sinton JM (eds) Mantle flow and melt generation at mid-ocean ridges, vol 71. Amer Geophysical Union, Washington, pp 281-310

Harrison TM, Watson EB (1984) The behavior of apatite during crustal anatexis: equilibrium and kinetic considerations. Geochim Cosmochim Acta 48:1467-1477

Hess P (1977) Structure of silicate melts. Can Mineral 15:162-178

Holness MB, Stripp G, Humphreys MCS, Veksler IV, Nielsen TFD, Tegner C (2011) Silicate liquid immiscibility within the crystal mush: late-stage magmatic microstructures in the Skaergaard intrusion, East Greenland. J Petrol 52:175-222

Hudon P, Jung I-H, Baker DR (2004) Effect of pressure on liquid-liquid miscibility gaps: a case study of the systems $\mathrm{CaO}-\mathrm{SiO}_{2}, \mathrm{MgO}-\mathrm{SiO}_{2}$, and $\mathrm{CaMgSi}_{2} \mathrm{O}_{6}-\mathrm{SiO}_{2}$. J Geophys Res 109:B03207

Humphreys MCS (2011) Silicate liquid immiscibility within the crystal mush: evidence from $\mathrm{Ti}$ in plagioclase from the Skaergaard intrusion. J Petrol 52:147-174

Jakobsen JK, Veksler IV, Tegner C, Brooks CK (2005) Immiscible iron- and silica-rich melts in basalt petrogenesis documented in the Skaergaard intrusion. Geology 33:885-888

Jakobsen JK, Veksler IV, Tegner C, Brooks CK (2011) Crystallization of the Skaergaard intrusion from an emulsion of immiscible iron- and silica-rich liquids: evidence from melt inclusions in plagioclase. J Petrol 52:345-373

Juster TC, Grove TL, Perfit MR (1989) Experimental constraints on the generation of FeTi basalts, andesites, and rhyodacites at the Galapagos spreading center, $85 \mathrm{~W}$ and $95 \mathrm{~W}$. J Geophys Res 94:9251-9274

Kerr AC, Kent RW, Thomson BA, Seedhouse JK, Donaldson CH (1999) Geochemical evolution of the Tertiary Mull volcano, western Scotland. J Petrol 40:873-908

Koster Van Groos AF, Wyllie PJ (1968) Liquid immiscibility in join $\mathrm{NaAlSi} \mathrm{O}_{3}-\mathrm{Na}_{2} \mathrm{CO}_{3}-\mathrm{H}_{2} \mathrm{O}$ and its bearing on genesis of carbonatites. Am J Sci 266:932-967 
Lee W-J, Wyllie PJ (1994) Experimental data bearing on liquid immiscibility, crystal fractionation, and the origin of calciocarbonatites and natrocarbonatites. Int Geol Rev 36:797-819

Leeman WP, Vitaliano CJ, Prinz M (1976) Evolved lavas from the snake river plain: craters of the moon national monument, Idaho. Contrib Mineral Petrol 56:35-60

Longhi J (1990) Silicate liquid immiscibility in isothermal crystallization experiments. Proceedings of the lunar planet science conference 20th, pp 13-24

Martin B, Kushiro I (1991) Immiscibility synthesis as an indication of cooling rates of basalts. J Volcanol Geotherm Res 45(3-4): 289-310

McBirney AR (1975) Differentiation of the Skaergaard Intrusion. Nature 253:691-694

McBirney AR (2008) Comments on: 'Liquid immiscibility and the evolution of basaltic magma' J Petrol 48, 2187-2210. J Petrol 49:2169-2170

Médard E, Grove T (2008) The effect of $\mathrm{H}_{2} \mathrm{O}$ on the olivine liquidus of basaltic melts: experiments and thermodynamic models. Contrib Mineral Petrol 155:417-432

Morse SA (2008) Compositional convection trumps silicate liquid immisciblity in layered intrusions: a Discussion of 'Liquid immiscibility and the evolution of basaltic magma' by Veksler et al., J Petrol 48, 2187-2210. J Petrol 49:2157-2168

Mysen BO (1983) The structure of silicate melts. Annu Rev Earth Planet Sci 11:75-97

Namur O, Charlier B, Toplis MJ, Higgins MD, Liégeois J-P, Vander Auwera J (2010) Crystallization sequence and magma chamber processes in the ferrobasaltic Sept Iles layered intrusion, Canada. J Petrol 51:1203-1236

Namur O, Charlier B, Toplis MJ, Higgins MD, Hounsell V, Liégeois J-P, Vander Auwera J (2011) Differentiation of tholeiitic basalt to A-type granite in the Sept Iles layered intrusion, Canada. J Petrol 52:487-539

Naslund HR (1983) The effect of oxygen fugacity on liquid immiscibility in iron-bearing silicate melts. Am J Sci 283:1034-1059

Philpotts AR (1979) Silicate liquid immiscibility in tholeiitic basalts. J Petrol 20:99-118

Philpotts AR (1982) Compositions of immiscible liquids in volcanic rocks. Contrib Mineral Petrol 80:201-218

Philpotts AR (2008) Comments on: liquid immiscibility and the evolution of basaltic magma. J Petrol 49:2171-2175

Philpotts AR, Doyle CD (1983) Effect of magma oxidation state on the extent of silicate liquid immiscibility in a tholeiitic basalt. Am J Sci 283:967-986

Putirka KD, Kuntz MA, Unruh DM, Vaid N (2009) Magma evolution and ascent at the craters of the moon and neighboring volcanic fields, Southern Idaho, USA: implications for the evolution of polygenetic and monogenetic volcanic fields. J Petrol 50:16391665

Roedder E (1978) Silicate liquid immiscibility in magmas and in the system $\mathrm{K}_{2} \mathrm{O}-\mathrm{FeO}-\mathrm{Al}_{2} \mathrm{O}_{3}-\mathrm{SiO}_{2}$ : an example of serendipity. Geochim Cosmochim Acta 42:1597-1617

Ryerson FJ, Hess PC (1978) Implications of liquid-liquid distribution coefficients to mineral-liquid partitioning. Geochim Cosmochim Acta 42:921-932

Schmidt MW, Connolly JAD, Günther D, Bogaerts M (2006) Element partitioning: the role of melt structure and composition. Science 312:1646-1650
Sisson TW, Grove TL (1993) Experimental investigations of the role of $\mathrm{H}_{2} \mathrm{O}$ in calc-alkaline differentiation and subduction zone magmatism. Contrib Mineral Petrol 113:143-166

Thy P, Lesher CE, Nielsen TFD, Brooks CK (2006) Experimental constraints on the Skaergaard liquid line of descent. Lithos 92:154-180

Toplis MJ, Carroll MR (1995) An experimental study of the influence of oxygen fugacity on $\mathrm{Fe}-\mathrm{Ti}$ oxide stability, phase relations, and mineral-melt equilibria in ferro-basaltic systems. J Petrol 36:1137-1170

Toplis MJ, Carroll MR (1996) Differentiation of ferro-basaltic magmas under conditions closed and open to oxygen: implications for the Skaergaard intrusion and other natural systems. J Petrol 37:837-858

Toplis MJ, Libourel G, Carroll MR (1994) The role of phosphorous in crystallization processes of basalt: an experimental study. Geochim Cosmochim Acta 58:797-810

Veksler IV (2009) Extreme iron enrichment and liquid immiscibility in mafic intrusions: experimental evidence revisited. Lithos 111:72-82

Veksler I, Dorfman A, Danyushevsky L, Jakobsen J, Dingwell D (2006) Immiscible silicate liquid partition coefficients: implications for crystal-melt element partitioning and basalt petrogenesis. Contrib Mineral Petrol 152:685-702

Veksler IV, Dorfman AM, Borisov AA, Wirth R, Dingwell DB (2007) Liquid immiscibility and the evolution of basaltic magma. J Petrol 48:2187-2210

Veksler IV, Dorfman AM, Borisov AA, Wirth R, Dingwell DB (2008) Liquid immiscibility and evolution of basaltic magma: Reply to S. A. Morse, A. R. McBirney and A. R. Philpotts. J Petrol 49:2177-2186

Veksler IV, Kahn J, Franz G, Dingwell DB (2010) Interfacial tension between immiscible liquids in the system $\mathrm{K}_{2} \mathrm{O}-\mathrm{FeO}-\mathrm{Fe}_{2} \mathrm{O}_{3^{-}}$ $\mathrm{Al}_{2} \mathrm{O}_{3}-\mathrm{SiO}_{2}$ and implications for the kinetics of silicate melt unmixing. Am Mineral 95:1679-1685

Villiger S, Ulmer P, Müntener O, Thompson AB (2004) The liquid line of descent of anhydrous, mantle-derived, tholeiitic liquids by fractional and equilibrium crystallization-an experimental study at 1.0 GPa. J Petrol 45:2369-2388

Villiger S, Ulmer P, Müntener O (2007) Equilibrium and fractional crystallization experiments at $0.7 \mathrm{GPa}$; the effect of pressure on phase relations and liquid compositions of tholeiitic magmas. J Petrol 48:159-184

Visser W, Koster van Groos AF (1979a) Phase relations in the system $\mathrm{K}_{2} \mathrm{O}-\mathrm{FeO}-\mathrm{Al}_{2} \mathrm{O}_{3}-\mathrm{SiO}_{2}$ at 1 atmosphere with special emphasis on low temperature liquid immiscibility. Am J Sci 279:70-91

Visser W, Koster van Groos AF (1979b) Effect of $\mathrm{P}_{2} \mathrm{O}_{5}$ and $\mathrm{TiO}_{2}$ on liquid-liquid equilibria in the system $\mathrm{K}_{2} \mathrm{O}-\mathrm{FeO}-\mathrm{Al}_{2} \mathrm{O}_{3}-\mathrm{SiO}_{2}$. Am J Sci 279:970-988

Visser W, Koster van Groos AF (1979c) Effect of pressure on liquid immiscibility in the system $\mathrm{K}_{2} \mathrm{O}-\mathrm{FeO}-\mathrm{Al}_{2} \mathrm{O}_{3}-\mathrm{SiO}_{2}-\mathrm{P}_{2} \mathrm{O}_{5}$. Am J Sci 279:1160-1175

Watson EB (1976) Two-liquid partition coefficients: experimental data and geochemical implications. Contrib Mineral Petrol 56:119-134

Wood MI, Hess PC (1980) The structural role of $\mathrm{Al}_{2} \mathrm{O}_{3}$ and $\mathrm{TiO}_{2}$ in immiscible silicate liquids in the system $\mathrm{SiO}_{2}-\mathrm{MgO}-\mathrm{CaO}-\mathrm{FeO}-$ $\mathrm{TiO}_{2}-\mathrm{Al}_{2} \mathrm{O}_{3}$. Contrib Mineral Petrol 72:319-328 